Review

\title{
Enzyme Initiated Radical Polymerizations
}

\author{
Frank Hollmann * and Isabel W. C. E. Arends
}

Department of Biotechnology, Delft University of Technology, Julianalaan 136, 2628BL Delft, The Netherlands; E-Mail: i.w.c.e.arends@tudelft.nl

* Author to whom correspondence should be addressed; E-Mail: f.hollmann@tudelft.nl;

Tel.: +31-15-27-81957; Fax: +31-15-27-81415.

Received: 30 January 2012; in revised form: 27 February 2012 / Accepted: 28 February 2012 /

Published: 6 March 2012

\begin{abstract}
Biocatalysis is propagating into practically every area of organic chemistry, amongst them radical polymerizations. A review of the recent developments of this dynamic and quickly evolving area of research is presented together with a critical evaluation of its potential to yield novel polymers and/or environmentally more benign synthetic procedures.
\end{abstract}

Keywords: radical polymerization; laccase; peroxidase; biocatalysis

\section{Introduction}

Great aspirations have been put on biocatalysts to make the chemical industry environmentally more benign and sustainable [1-3]. Indeed, more and more examples impressively demonstrate the potential of White Biotechnology to reduce resource consumption and waste generation [1,4-6]. However, most of the 'landmark' examples deal with the synthesis of small, chiral molecules useful for pharmaceuticals etc. Traditionally, the wastes generated in this industry are enormous, leaving room for significant improvements [7]. The global impact, however, is limited by the comparably low production volumes.

In contrast, polymers are bulk products produced in huge annual quantities. Here, though the saving potential might be lower due to highly optimized 'traditional' production schemes, even comparably small improvements may have a dramatic global impact. Hence, it is not astonishing that biocatalysis is also enjoying growing interest in the field of polymers [8]. One field that has expanded tremendously in the past two decades is the enzyme-initiated radical polymerization of aromatic and 
vinyl monomers [8-12]. In this contribution, we summarize and critically evaluate the past and recent developments in this field also giving an outlook of the future perspectives.

\section{Mechanism(s) of Enzyme Initiated Radical Polymerizations}

Two enzyme classes dominate the field of biocatalytic radical polymerization: peroxidases (EC 1.11.1) and laccases (EC 1.10.3.2). Though quite different with respect to catalytic mechanism and active site structure, both enzyme classes predominantly catalyze hydrogen abstraction reactions yielding radical species to initiate the polymerization reaction. Other enzyme classes such as oxidases or lipoxygenases play only a minor role [13-15].

\subsection{Peroxidase-Initiated Polymerizations}

By far the most popular catalysts for the enzymatic initiation of radical polymerization (both of aromatic and vinyl monomers) are the so-called heme peroxidases. Particularly, the peroxidases from horseradish (HRP) and soybean (SBP) have been used most frequently.

These peroxidases contain protoporphyrin IX (heme, Figure 1) as prosthetic group with low-spin $\mathrm{Fe}^{\mathrm{III}}$ in the resting state $[16,17]$.

Figure 1. Resting state of heme peroxidases. In the majority of cases L constitutes a histidine ligand.

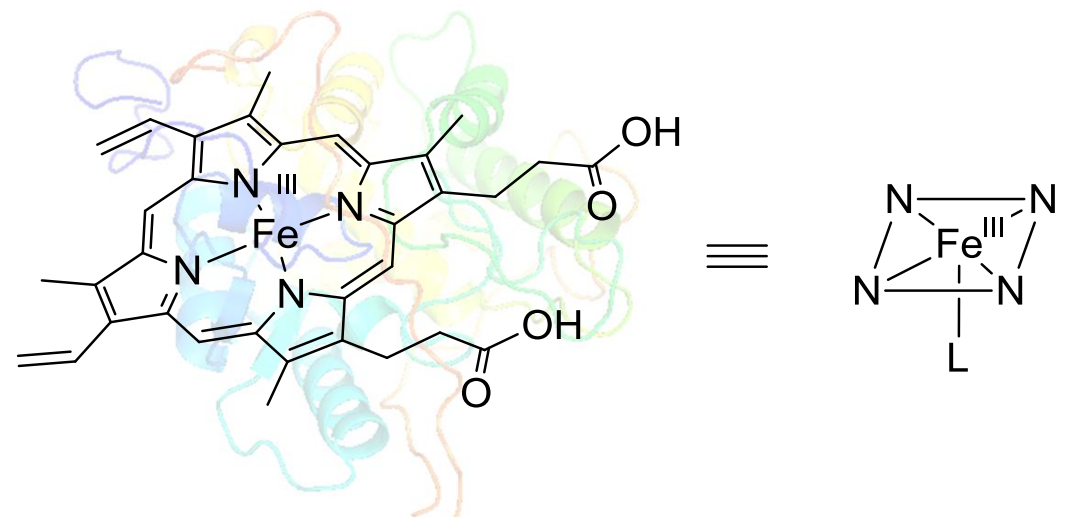

During the catalytic mechanism (Figure 2) the water ligand (intermediate 1) is substituted by hydrogen peroxide (or other organic hydroperoxides) resulting in a peroxo complex (intermediate 2). Upon heterolytic cleavage of the O-O bond the so-called compound I (Cpd-I) is formed. Cpd-I returns into the resting state by two individual hydrogen abstractions from the reducing substrates (In-H) resulting in the formation of two radical species (In·) which then initiate the polymerization process. Overall, peroxidases function as 'electron relays' coupling a two electron transfer step (reduction of peroxides to water or alcohols, respectively) to two subsequent single electron transfer steps.

$\mathrm{H}_{2} \mathrm{O}_{2}$ plays an ambivalent role in the peroxidase-initiated polymerization reaction. On the one hand, it serves as oxidant and therefore is essential for the catalytic action. On the other hand, if $\left[\mathrm{H}_{2} \mathrm{O}_{2}\right]$ is too high, polymerization is inhibited twofold: (1) $\mathrm{H}_{2} \mathrm{O}_{2}$ is a known inactivator of heme [18,19]. It was proposed that in the presence of an excess of $\mathrm{H}_{2} \mathrm{O}_{2}$ Cpd-II reacts with another equivalent of $\mathrm{H}_{2} \mathrm{O}_{2}$ instead of returning to the resting state. The resulting Cpd-III decomposes along various pathways 
leading to irreversible enzyme inactivation [19]. (2) A catalase-like activity of peroxidases [20] at high $\left[\mathrm{H}_{2} \mathrm{O}_{2}\right]$ results in the generation of $\mathrm{O}_{2}$ thereby inhibiting the chemical polymerization reaction. This effect has been reported especially for the polymerization of vinyl monomers in form of a lag-phase. During this lag phase, remaining $\mathrm{O}_{2}$ is consumed, probably by reaction with $\mathrm{In}$. The resulting superoxide anion $\left(\mathrm{O}_{2}{ }^{-}\right)$disproportionates quickly thereby overall accounting for a futile consumption of $\mathrm{H}_{2} \mathrm{O}_{2}$ and radical quenching. It should, however, be emphasized that the exact mechanism remains to be elucidated. Polymerization only proceeds if $\mathrm{O}_{2}$ formed by the catalase-activity has been consumed [21].

Figure 2. Simplified catalytic mechanism of peroxidase-catalyzed radical formation. In the majority of cases $\mathrm{L}$ is a histidine ligand but can also be cysteine.

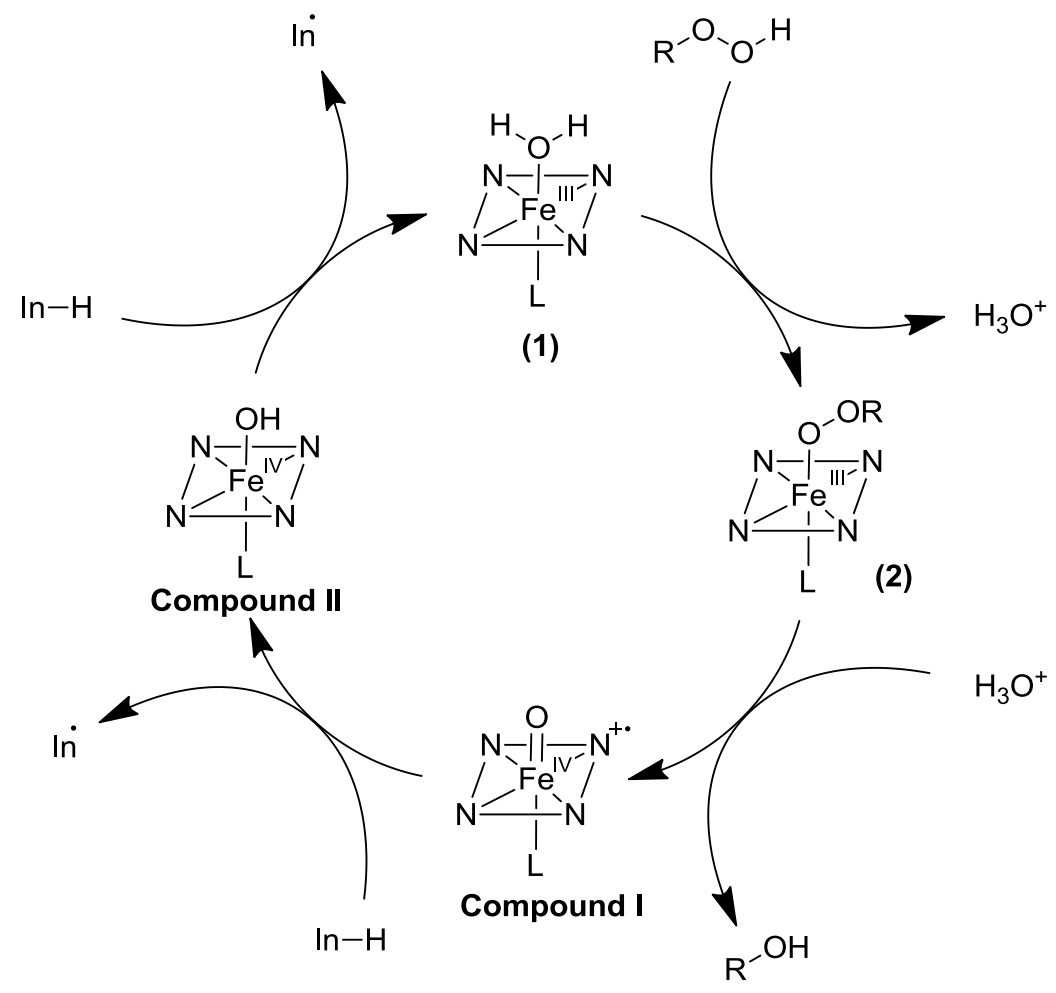

The usual way of avoiding excess $\mathrm{H}_{2} \mathrm{O}_{2}$ is to add $\mathrm{H}_{2} \mathrm{O}_{2}$ in several portions, which turns out to be tedious and also bears the danger of leading to a certain degree of irreproducibility. Therefore, a range of in situ $\mathrm{H}_{2} \mathrm{O}_{2}$ generation methods have been proposed, [22-24] which might be useful also for peroxidase-initiated polymerizations. Indeed Uyama et al. and others reported a bienzymatic system for the polymerization of phenols comprising peroxidase as the initiation catalyst and glucose oxidase as in situ $\mathrm{H}_{2} \mathrm{O}_{2}$ generation catalyst (Figure 3) [25,26].

Interestingly, this system, despite its simplicity, has not found broad proliferation. Possibly, inhibitory effects of $\mathrm{O}_{2}$ are quite severe in practice.

A rather unusual in situ generation of peroxo species was found accidentally by Samuelson and coworkers [27]. They found that a dioxane stabilizer (acetyl acetal) spontaneously hydrolyzed under the reaction conditions and was oxidized to peracetic acid, which then served as oxidant to initiate the polymerization of aniline (Figure 4). 
Figure 3. Bienzymatic polymerization reaction. Glucose oxidase (GOx) catalyzes the reduction of $\mathrm{O}_{2}$ to $\mathrm{H}_{2} \mathrm{O}_{2}$ which then initiates the polymerization reaction.

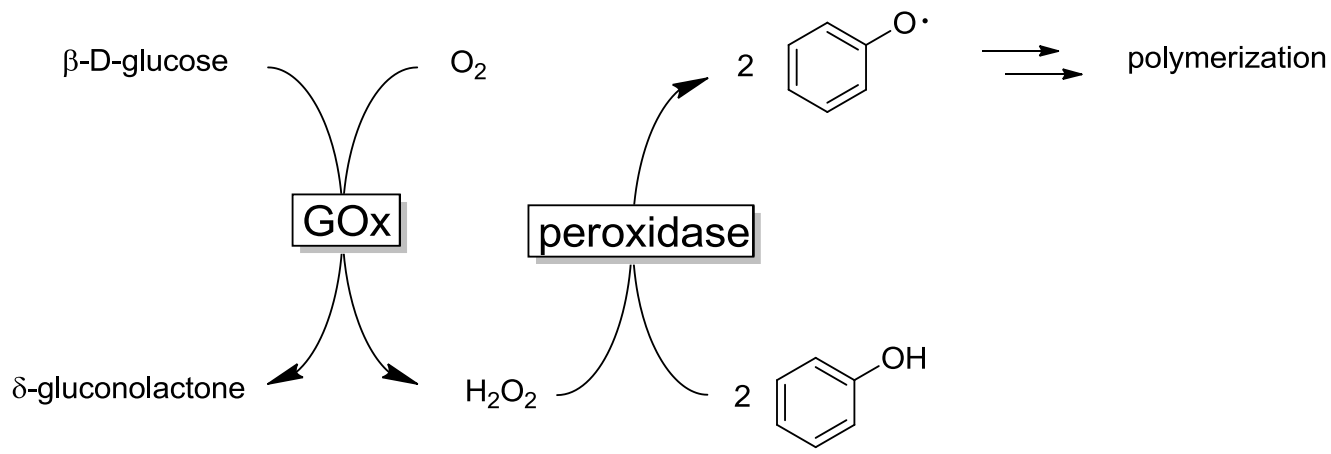

Figure 4. In situ formation of peracetic acid from a solvent stabilizer to initiate horseradish (HRP)-catalyzed polymerizations.

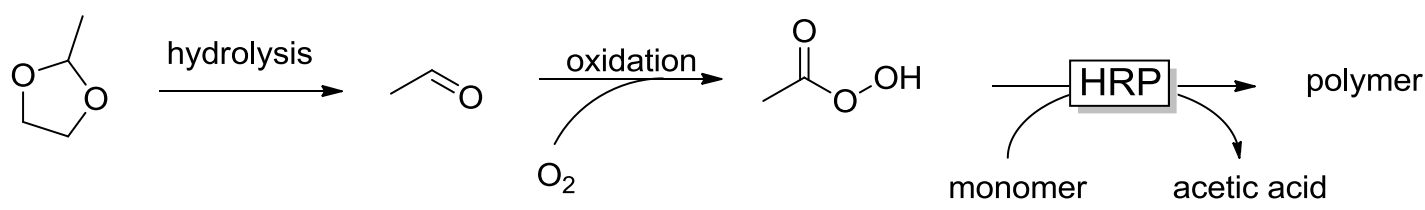

Nevertheless, portionwise addition of $\mathrm{H}_{2} \mathrm{O}_{2}$ remains the most popular procedure to promote peroxidase-initiated polymerizations.

\subsection{Laccase-Initiated Polymerization}

Laccases (E.C. 1.10.3.2) belong to the so-called blue-copper oxidases predominantly found in fungi but also in plants and insects [28-31]. Laccases catalyze hydrogen abstraction reactions from phenolic and related substrates resulting in corresponding phenoxy radicals. They contain four copper ions classified in one T1 copper ion and a T2/T3 cluster. It has been shown that the T1 site is the primary redox center accepting electrons from the electron donors. Thus, the fully oxidized laccase is transformed via four successive, fast single electron transfer (SET) steps into the fully reduced laccase. Molecular oxygen interacts with the fully reduced (T2/T3) cluster via a fast 2-electron-transfer process. The resulting peroxide is tightly bound so that release of $\mathrm{H}_{2} \mathrm{O}_{2}$ prior to the second 2-electron-transfer is efficiently prevented. As a result, the fully oxidized form of laccases comprising a $\mu_{3}$-oxo-bridged trinuclear (T2/T3) site is formed. This structure is thermodynamically relatively stable and provides the driving force for the overall process and also provides an efficient electron transfer bridge to re-generate the fully reduced state (Figure 5).

Interestingly enough, the number of publications dealing with laccase-initiated polymerization falls back significantly behind peroxidase-initiated polymerization studies. This is astonishing insofar as the laccase-based systems appear to be significantly easier. One apparent advantage is that laccases utilize molecular oxygen instead of hydrogen peroxide as oxidant, but inhibition may prevent widespread use. 
Figure 5. Schematic mechanism for laccase-catalyzed radical formation.

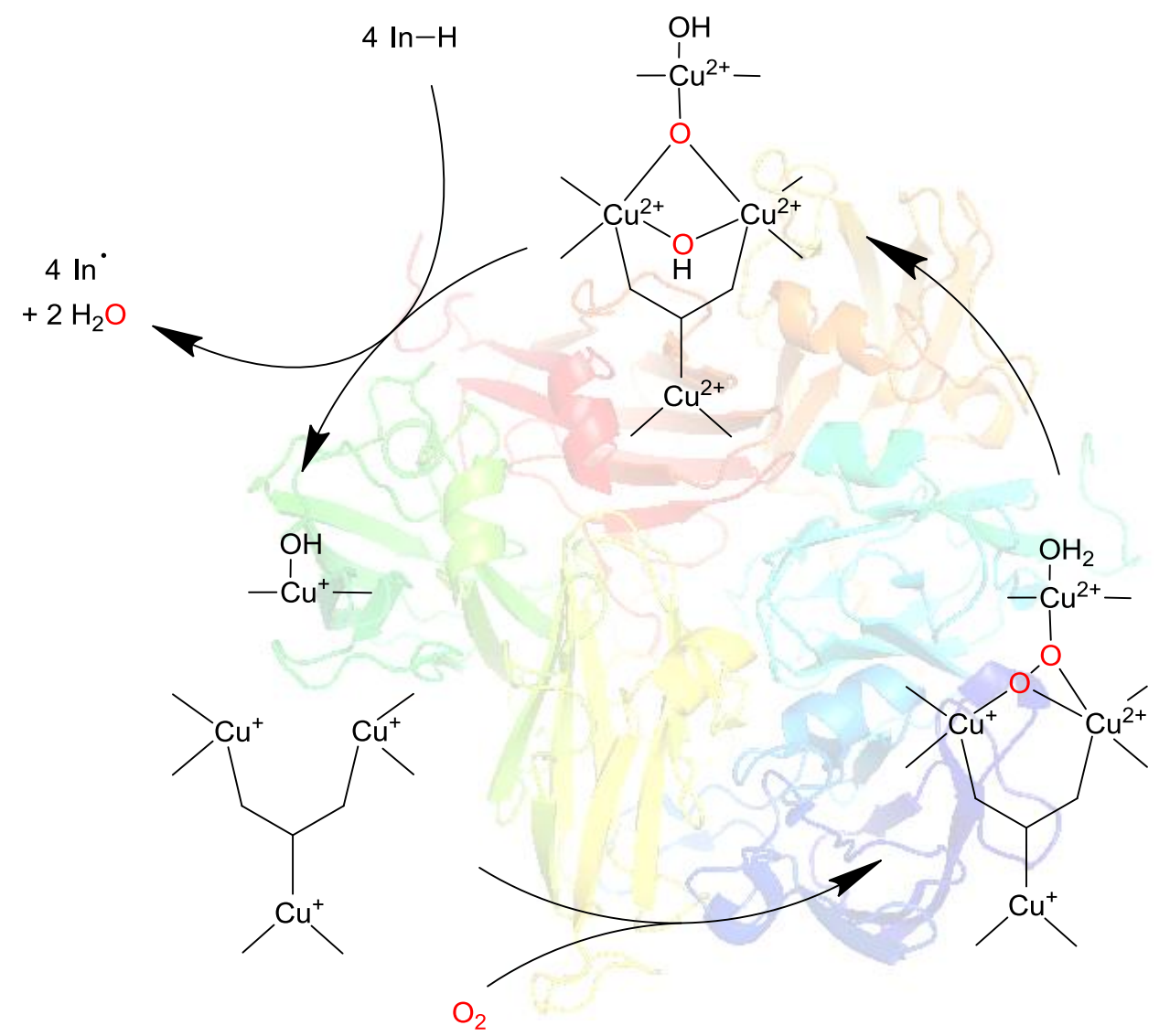

\subsection{Laccase-/Peroxidase-Mediator-Systems (LMS/PMS)}

Often direct oxidation of the monomers is not possible due to unfavorable steric interaction with the enzymes' active sites and/or due to unfavorable redox potentials. In such cases, initiation of the polymerization reaction may take place by so-called laccase- or peroxidase mediator systems (LMS or PMS, respectively). Here, enzymatic chain initiation does not proceed directly on a monomer molecule but indirectly via a small, oxidizable mediator (Figure 6). Two mechanisms can be distinguished: First, the mediator can serve as radical transfer catalyst without being incorporated into the final product. Phenothiazenes, for example, have been used to initiate the polymerization of sterically demanding phenols, [32,33] or ABTS to facilitate pyrrole polymerization [34,35]. Also transition metals (e.g., $\mathrm{Mn}^{2+/ 3+}$ ) [36] or polyoxometallates [37] have been reported. Second, the mediator radical itself can initiate chain growth thereby being incorporated into the polymer (see Section 2.4). This mechanism is the predominant pathway for the polymerization of vinyl monomers with $\beta$-diketones representing the mediators of choice (vide infra) but may also be applicable for the polymerization of non-phenolic aromatics such as thiophenes [38]. 
Figure 6. Schematic representation of laccase mediator systems (LMSs) and peroxidase mediator systems (PMSs) initiated polymerization reactions. Upper: the mediator is used as true catalyst transferring the radical to a monomer; Lower: the oxidized mediator radical itself initiates the polymerization process and hence is incorporated into the polymer.
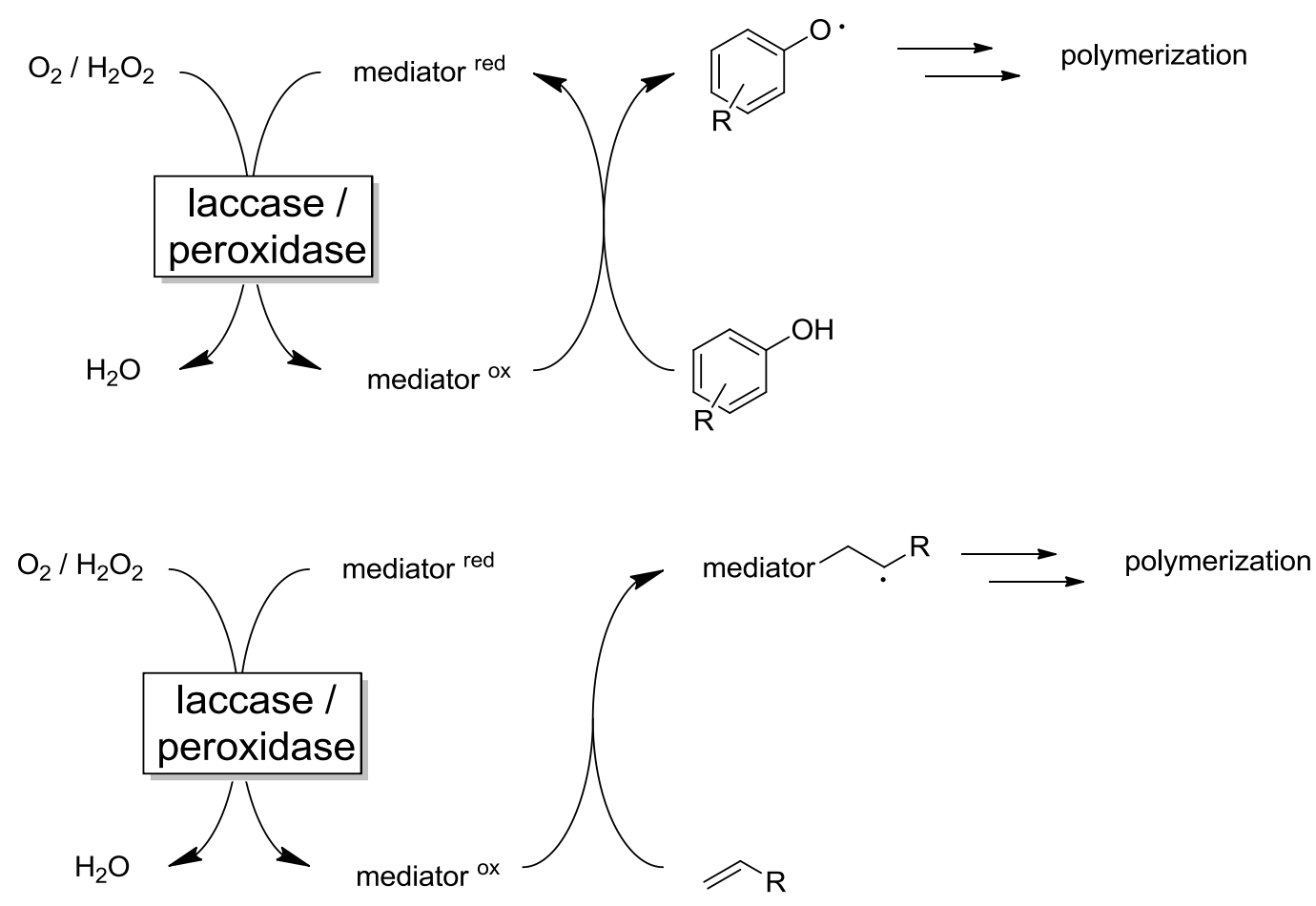

\subsection{Other Enzyme Systems/Miscellaneous}

Very recently the groups around Bruns [39] and di Lena [40,41] independently reported on biocatalytic atom transfer radical polymerizations.

Using laccases or heme-enzymes such as catalase of HRP, an ATRP-like polymerization was achieved with ascorbic acid as reductant and $\alpha$-bromoesters as initiators. Despite the very early stage of development (particularly further mechanistic studies clarifying the initiation reaction are needed), this approach represents already now a very promising biocatalytic alternative to the existing toolbox [42]. Exciting further developments are expected here in the near future. Noteworthy, this approach also represents the first example(s) of a reductively initiated radical polymerization.

Ximenes and coworkers reported on the $\mathrm{H}_{2} \mathrm{O}_{2}$-independent Acac oxidation by HRP in the presence of molecular oxygen [43]. Intermediate formation of Acac and superoxide was postulated, which might potentially be exploited for the initiation of radical polymerizations. If feasible, such a pathway might open up new possibilities while circumventing the limitations of $\mathrm{H}_{2} \mathrm{O}_{2}$-promoted chain initiation reactions mentioned above. It remains to be shown whether such a mechanism might be fruitfully exploited for peroxidase-initiated polymerization reactions.

\section{Controlling the Structure of the Polymers}

Unlike most enzymatic transformations, oxidoreductase-initiated radical polymerizations lack any influence of the biocatalyst on the structure of the final product. Hence, if control over the structure 
and morphology of the polymer formed is desired, this has to be achieved with a mechanism which does not directly involve the enzyme. In the following some of the strategies generally applied are discussed.

\subsection{Controlling Vinyl Polymerization}

The major concern in vinyl polymerization is to control the polymer weight and polydispersity of the final product. In this respect, most studies have focused on the influence of biocatalyst-, mediator-, and oxidant concentration.

The biocatalyst concentration directly correlates with the chain initiation rate and thereby influences the number of growing chains in the reaction mixture and competing for the remaining monomers. As a rule of thumb, the higher the biocatalyst concentration the lower the average polymer weight, as demonstrated for peroxidases [44] and laccases [45]. At very high enzyme concentration, the initiation rate can be so dominant that only oligomers are formed. Under denaturizing conditions, too low enzyme concentrations manifest in low conversions due to enzyme inactivation [46].

Like enzyme concentration, choice and concentration of the mediator can have a major impact on the polymer properties. This was demonstrated by Kaplan and coworkers on the HRP-initiated polymerization of styrene and by Marechal and coworkers for the polymerization of acrylamide (Table 1) [47,48].

Table 1. Influence of various $\beta$-diketone mediators in the polymer properties.

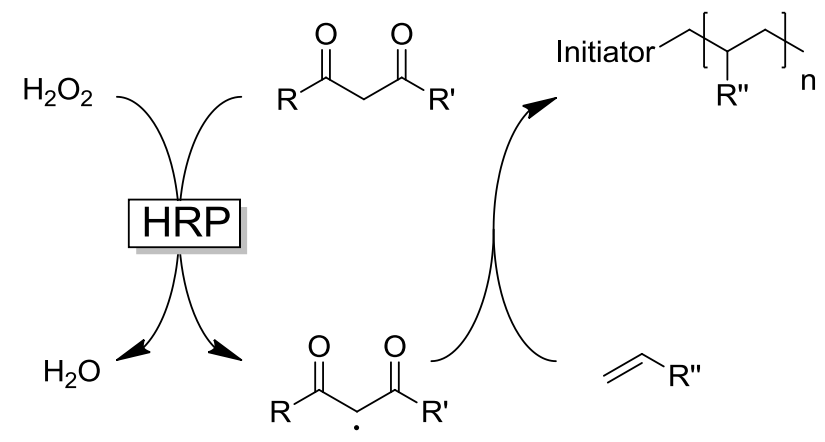

\begin{tabular}{|c|c|c|c|}
\hline Initiator & Yield [\%] & $\mathrm{M}_{\mathrm{W}}\left[\times 10^{-3} \mathrm{~g} \cdot \mathrm{mol}^{-1}\right]$ & PD \\
\hline \multicolumn{4}{|c|}{ Styrene polymerization [47] } \\
\hline & 17 & 27 & 2.1 \\
\hline & 59 & 68 & 2.0 \\
\hline & 14 & 80 & 2.0 \\
\hline & 14 & 97 & 2.2 \\
\hline & 14 & 57 & 1.6 \\
\hline
\end{tabular}


Table 1. Cont.

\begin{tabular}{|c|c|c|c|}
\hline Initiator & Yield [\%] & $\mathrm{M}_{\mathrm{W}}\left[\times 10^{-3} \mathrm{~g} \cdot \mathrm{mol}^{-1}\right]$ & PD \\
\hline \multicolumn{4}{|c|}{ Acrylamide polymerization [48] } \\
\hline & 93 & 124 & 2.5 \\
\hline & 84 & 56 & 2.9 \\
\hline & 76 & 5 & 4.4 \\
\hline & 72 & 27 & 3.3 \\
\hline & 78 & 85 & 2.7 \\
\hline & 38 & 10.5 & 3.9 \\
\hline
\end{tabular}

So far, detailed studies clarifying the influence of $\beta$-diketone structure on enzyme activity are missing. Most likely, both steric and electronic effects influence the rate of the enzymatic initiation reaction as well as the rate of the chain growth (at least at an early stage of the chain growth).

It is generally assumed that the enol form represents the actual substrate for the enzymatic radical formation reaction (Figure 7) [49].

Figure 7. $\beta$-Diketones as polymerization initiators.<smiles>[R]C(=O)C=C([R])O</smiles>

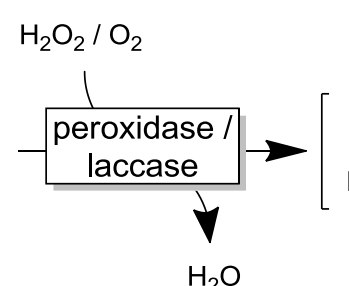

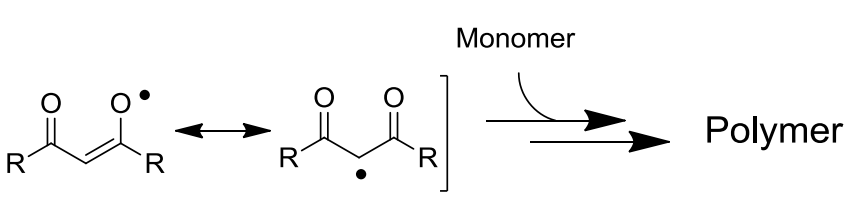

The state of the keto-enol equilibrium should determine the actual substrate concentration. Hence, high $\mathrm{pH}$ values should be beneficial as well as using elevated substrate concentrations. However, these measures may also be counteracted by a decreasing activity of the biocatalyst under these conditions. Principally, electron withdrawing substituents should increase the enzyme rate by shifting the keto-enol equilibrium and lowering the redox potential on the one hand. On the other hand, the resulting radical might be too stable due to very low lying SOMO energy.

Obviously, the ratio of monomer to initiator has a strong influence on the average size of the resulting polymer. The number of growing polymer chains, competing for the remaining monomer reservoir, increases with initial initiator concentration (Figure 8) [44]. 
Figure 8. Influence of the monomer-mediator ratio on the properties of poly(acrylamide).

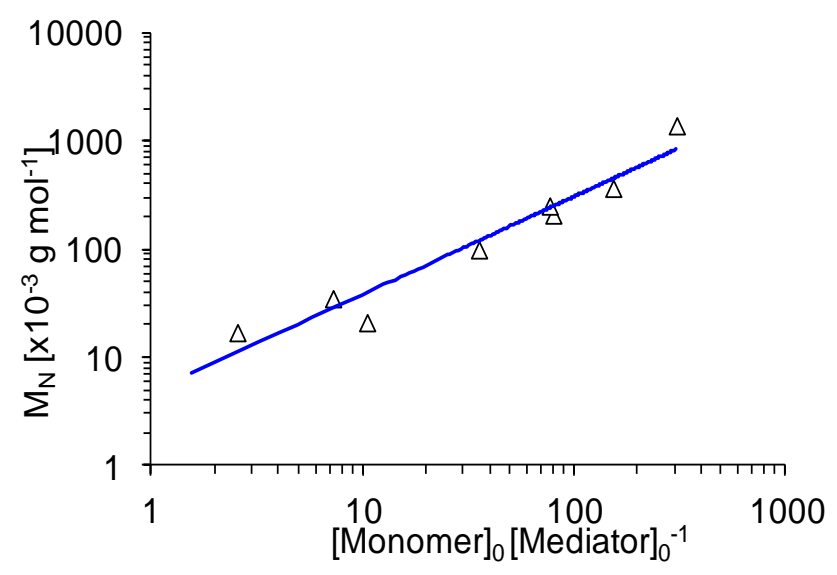

There is an ongoing discussion about the necessity of B-diketones to initiate the polymerization reaction. Earlier reports on $\beta$-diketone-free polymerization of acrylamide [13,50] could not be reproduced by others $[48,51]$. One potential solution of this apparent discrepancy may be found in the very high $\mathrm{H}_{2} \mathrm{O}_{2}$ concentration in the mediator-free polymerizations resulting in 'unusual' heme-iron species [19]. Thus, highly reactive peroxidase-species might initiate the polymerization reaction by direct $\mathrm{H}$-atom abstraction from the monomer. Alternatively, oxidative degradation of heme resulting of Fe-release into the reaction medium might account for catalytic, Fenton-like generation of reactive oxygen species (ROS) initiating the polymerization reaction.

Kobayashi and coworkers reported on the mediator-free direct polymerization of acryl amide using the laccase from Pycnoporus coccineus suggesting a simplified polymerization scheme [52]. Using the laccase from Myceliophthora thermophilia, this was not achieved [14,45] and a follow-up study validating Kobayashi's initial study is still missing.

Particularly when using laccases, molecular oxygen plays an ambivalent role. On the one hand, $\mathrm{O}_{2}$ serves as stoichiometric oxidant to initiate the polymerization reaction. On the other hand, excess $\mathrm{O}_{2}$ can also efficiently quench the radical polymerization [45,53].

Recently, Nieto et al. reported on an interesting approach to balance the in situ $\mathrm{O}_{2}$ concentration for laccase-initiated polymerization by co-application of glucose oxidase as additional $\mathrm{O}_{2}$-consuming reaction [54].

\subsection{Controlling Polymerization of Aromatics}

In contrast to the above-mentioned polymerization of vinyl monomers, regioselectivity also plays an important role in the polymerization of phenols and anilines. Hence, many efforts have been directed towards gaining control over the chemo- and regioselectivity of the enzymatic polymerization of phenols and anilines.

\subsubsection{Cosolvents}

Also due to the poor aqueous solubility of most aromatic substrates, the influence of co-solvents is frequently addressed [55,56]. In some cases significant control over the polymer size and polydispersity has been achieved with organic solvents. For example, Dordick et al. observed changes 
in the average polymer weight of poly(phenol) from 1,000 to over $26,000 \mathrm{~g} \cdot \mathrm{mol}^{-1}$ upon varying the 1,4-dioxane content in the polymerization reactions [57]. Oguchi et al. reported on the HRP-initiated polymerization of phenol in aqueous methanol solutions yielding number average molecular weights up to $5200 \mathrm{~g} \cdot \mathrm{mol}^{-1}$ [58]. Mita et al. have investigated various polar solvents and their influence on the chemoselectivity of the peroxidase-initiated polymerization of phenols (Figure 9) [59,60]. Also the hydrophobicity of the starting material had an influence on the C-C vs. C-O selectivity: the higher the hydrophobicity, the higher was the C-C- selectivity. Later on the same authors substantiated these results also using laccase as catalyst [61,62].

Figure 9. Influence of cosolvent on the peroxidase-initiated polymerization of 4-butylphenol. left: influence of different $\log$ Ps on the selectivity of the bond formation and polymer weight; right: chemoselectivity at different co-solvent concentrations.
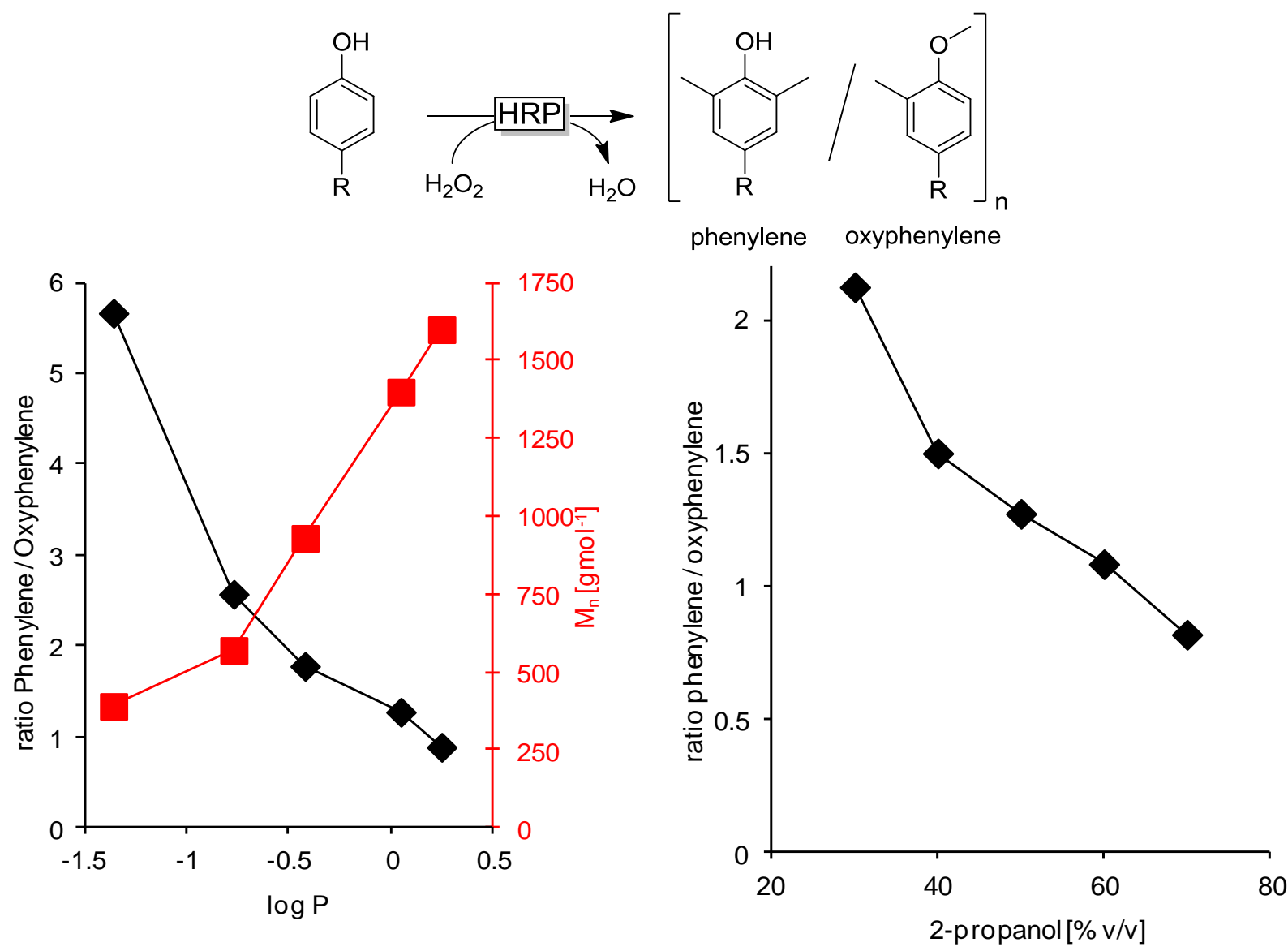

In addition to classical organic solvents, also ionic liquids have received some attention as cosolvents to increase the solubility of the phenolic monomers. Interestingly, while Sgalla et al. [63]. reported the exclusive formation of dimers using HRP in $[\mathrm{BMIM}]\left[\mathrm{BF}_{4}\right]$, Eker et al. later on reported on the generation of comparably large polymers using the same IL as cosolvent [64]. Obviously, more research will be necessary to fully understand the effect of ILs as cosolvents to support enzymatic polymerizations [65].

Ionic liquids can also be used as liquid support for enzyme immobilization as demonstrated by Rumbau et al. [66]. HRP immobilized in [BMIM][PF 6$]$ was applied in an emulsion polymerization of aniline (using dodecylbenzensulfonate as anionic template, vide infra). After the reaction, the aqueous 
product phase was separated from the enzyme-containing IL which could be reused at least 5 times without significant changes in the product properties (Figure 10).

Figure 10. [BMIM] $\left[\mathrm{PF}_{6}\right]$ as liquid support for the immobilization/recycling of HRP.

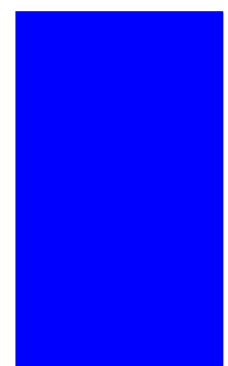

1
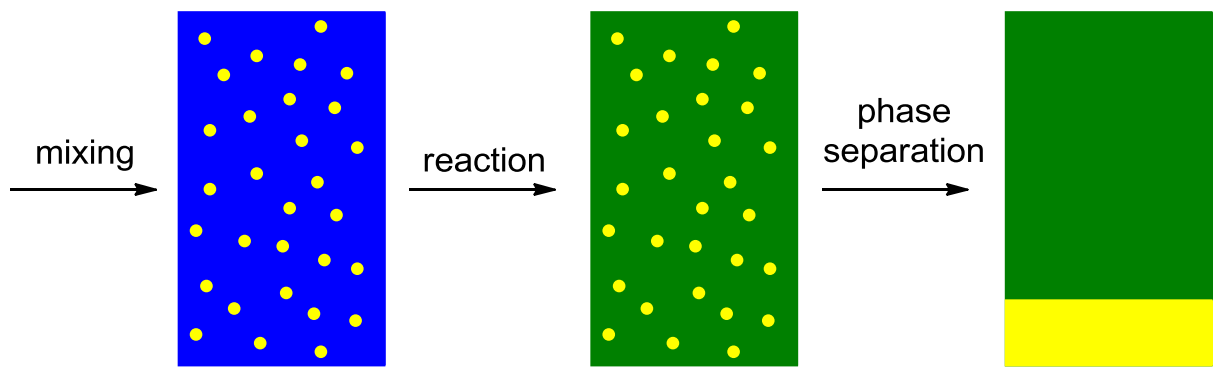

recyclying of IL/enzyme phase

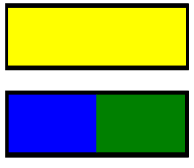

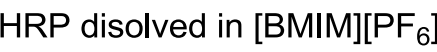

aqueous phase with aniline/poly(aniline)

Cyclodextrines have been evaluated as alternatives to organic cosolvents to increase the solubility of hydrophobic phenols [67-69].

Figure 11. HRP solubilized in organic solvents by charge compensation/hydrophobization with AOT (anionic surfactant).

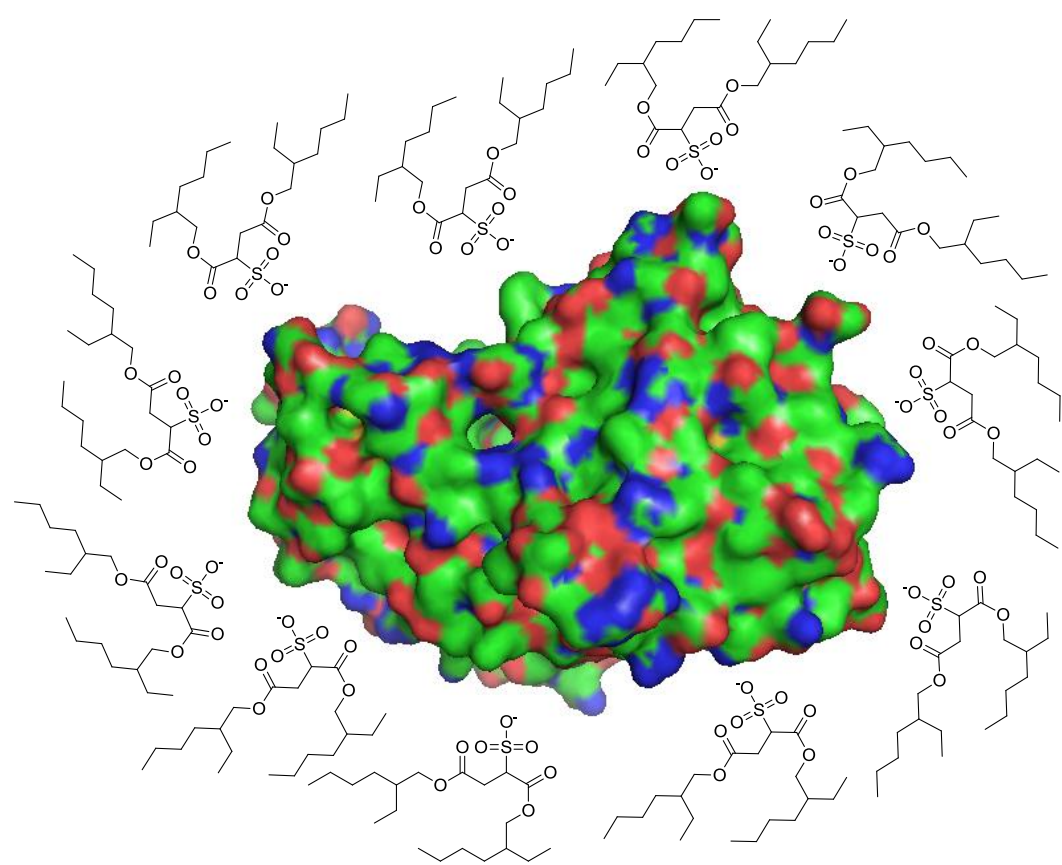

Of course, (almost) non-aqueous reaction media would solve the solubility issue of phenols. Furthermore, anhydrous conditions can significantly alter the outcome of a given enzyme reaction. For example, as early as 1986, Dordick et al. reported that HRP catalyzes the depolymerization of lignin model compounds in $95 \%$ dioxane whereas under aqueous conditions no depolymerization 
activity was detectable $[57,70]$. Of course the solubility of native polypeptides in non-aqueous reaction media is practically zero, leading to severe diffusion limitations when using immobilized biocatalysts. However, under certain conditions enzymes can be made organosoluble e.g., by chemical modification (acetylation), [57,70] or ion pairing with anionic surfactants [71] or calixarenes [72]. For example, $\mathrm{Li}$ and coworkers could make HRP soluble in isooctane by ion pairing it with the anionic surfactant aerosol OT (AOT) (Figure 11). The resulting organosoluble HRP was used in the tBuOOH-driven polymerization of hexylphenol [71].

\subsubsection{Templates}

There are a number of investigations in which templates have been used for controlling the chemical structure of polymers synthesized by oxidoreductase-initiated polymerization. Very recently, Walde and Gou gave an excellent overview over the present state of the art [73], which is why here only a few representative examples are discussed.

Poly(styrenesulfonate) (PSS) represents one of the first an most widely applied templates to control polymerizations. Special interest has been paid to the polymerization of aniline to the conducting polymer form (emeraldine). In the absence of a suitable template aniline polymerizes with poor regioselectivity yielding complex, insoluble and non conducting polymers. However, e.g., in the presence of negatively charged PSS (and in the presence of protonated aniline, i.e., at suitable pHs) formation of the conducting emeraldine form is strongly favored (Figure 12) [27,73-79].

Figure 12. Reaction products obtained by radical polymerization (e.g., in the system $\mathrm{HRP} / \mathrm{H}_{2} \mathrm{O}_{2}$ ) of aniline. In the absence of templates (upper) and e.g., using PSS as template.
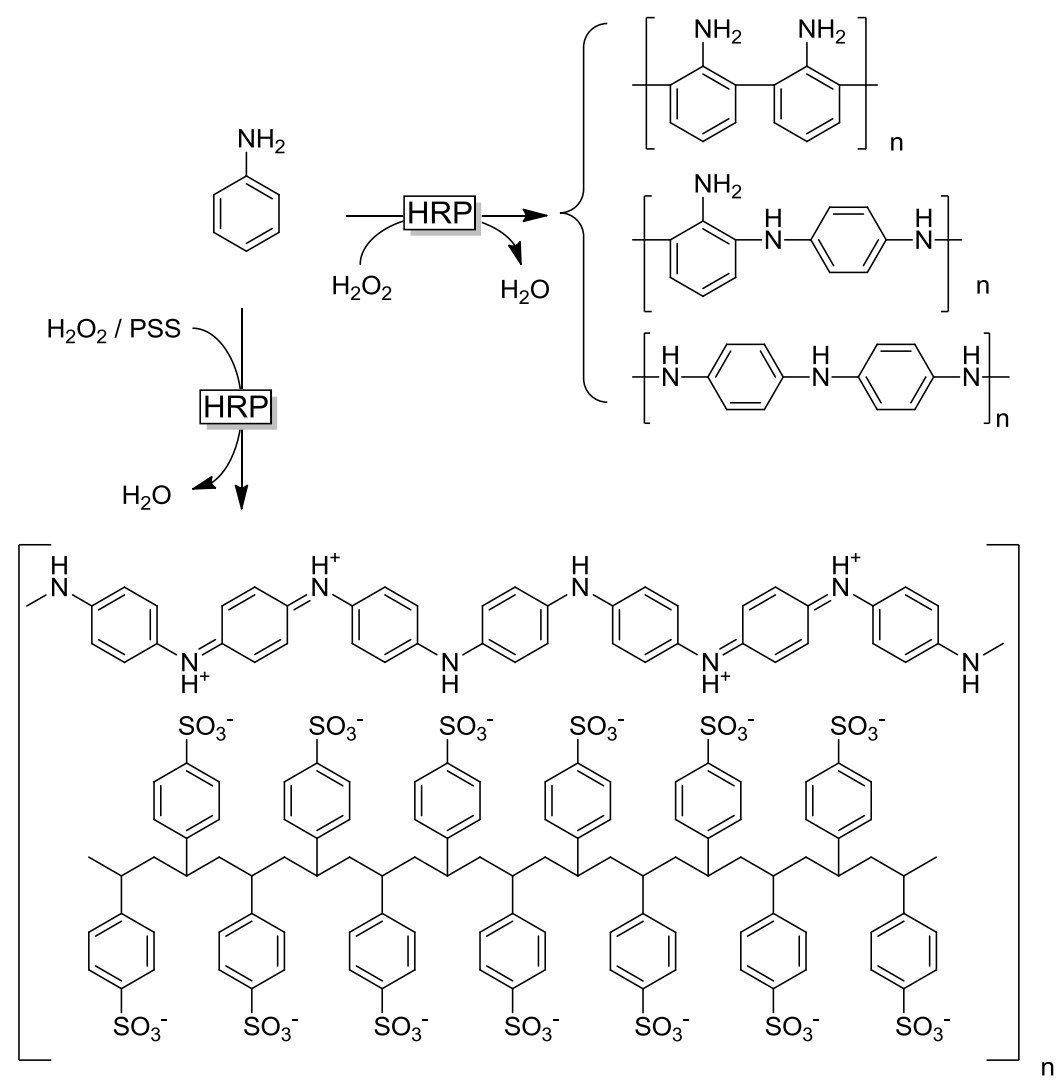
Other negatively charged polymers [80] such as poly(vinylphosphonic acid) [81] or DNA [82-84] have been reported as templates. The templates promote the formation of the electrically conducting emeraldine form of poly(aniline) and significant branching (as in case of in the absence of the templating agent) does not occur. The template is thought to at least partially lead to a proper alignment of the monomers and the growing chain; another role of the negatively charged template is to serve as counter ion (dopant) influencing the charge and conformation of the polyaniline and thereby its electronic properties. In addition, anionic surfactants under emulsion conditions have been reported as templates $[85,86]$. Using PSS as template also proved to be suitable to produce poly(pyrroles) with improved conductiveness [87].

Templated polymerization of phenols can be achieved also using uncharged templates such as poly(ethylene glycol) and others [88-92]. Probably due to H-bond-mediated phenol-template interactions, a certain degree of regioselectivity favoring phenylene connections over oxyphenylenes was observed [89-91]

Interestingly, using carbon nanotubes as polymerization templates, Liu and coworkers observed oxyphenylene selectivity in the polymerization of phenol [93].

Another very interesting templating effect was reported by $\mathrm{Xu}$ et al. who caffeic acid onto a p-aminothiophenol-modified gold surface [94]. Oriented adsorption of the phenolic monomer was achieved via inonic and $\mathrm{H}$-bond interactions of the substrate with the amino-modified surface. As a result, the laccase- or HRP-initiated polymerization proceeded with very high phenylene selectivity whereas under 'normal aqueous' polymerization conditions a mix of phenylene and oxyphenylene connections was observed (Figure 13).

Figure 13. HRP-initiated chemoselective polymerization of caffeic acid templated by a $\mathrm{NH}_{2}$-modified Au-electrode.

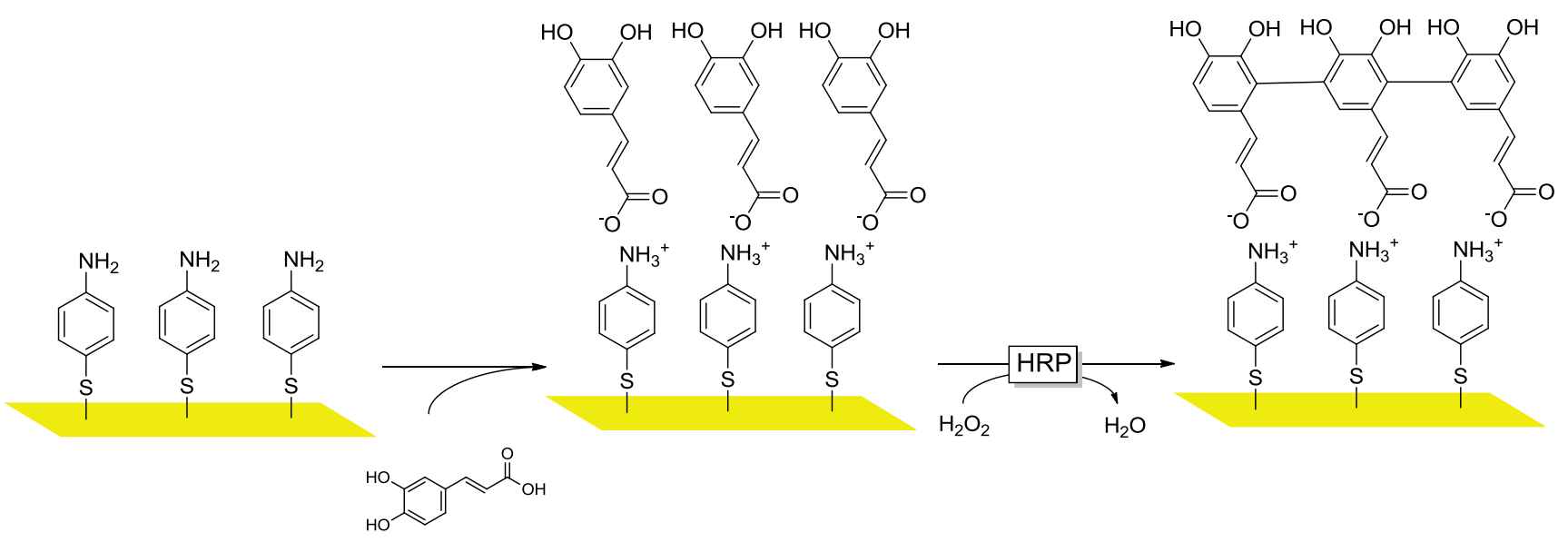

\subsubsection{Substrate Engineering}

Also the structure of the monomers themselves can significantly influence the selectivity of the polymerization reaction. For example Mita et al. [60] showed that the phenylene content of poly(p-substituted phenols) increased with the hydrophobicity of the substituent. Blocking the o-position of aniline enabled selective polymerization of anilines yielding conductive emeraldines without the need for a template [27]. 
Another interesting example is the polymerization of $p$-hydroxy benzoic acid (derivates), which proceeds highly regioselectively producing oxyphenylene connections exclusively (Figure 14) [95].

Figure 14. Proposed regioselective polymerization mechanism for $p$-hydroxy benzoates.

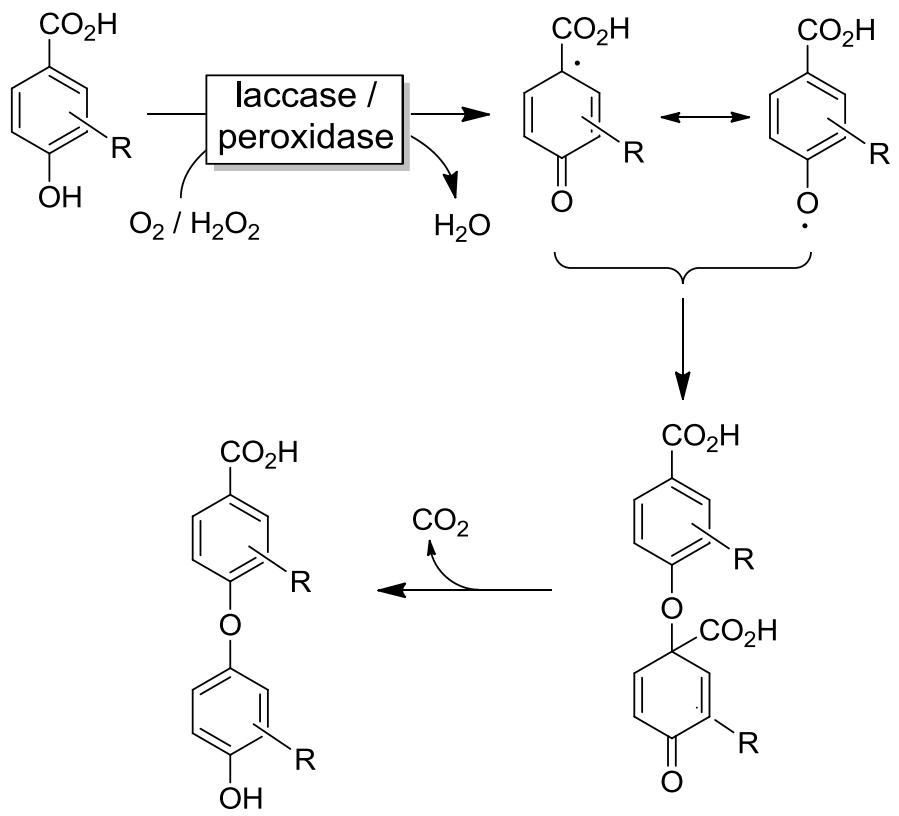

Figure 15. Multi-enzyme synthesis of poly(hydroquinone).

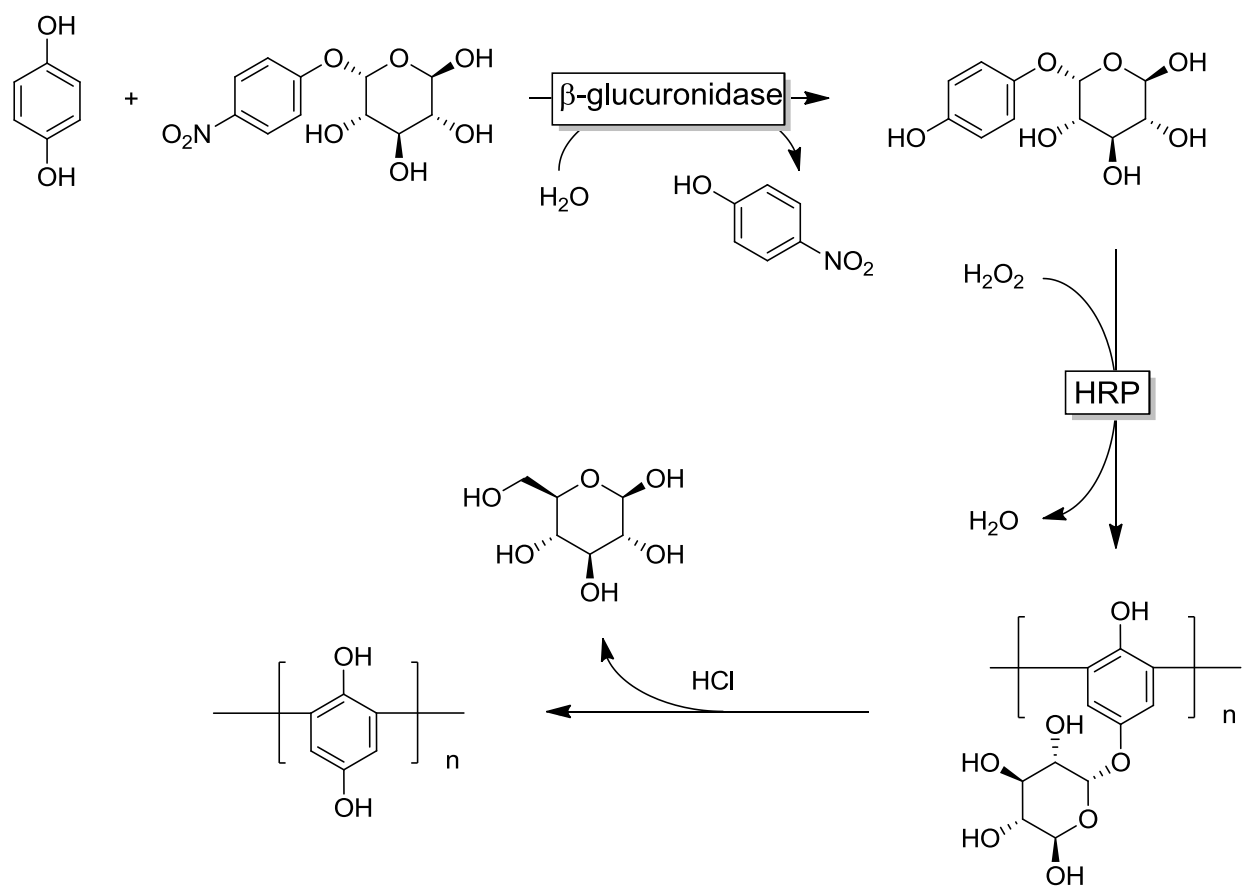

Polymerization of catechols and hydroquinones can be tedious due to facile oxidation to the corresponding quinones. This can be overcome by blocking of one of the $\mathrm{OH}$-functionalities as demonstrated by Dordick and coworkers (Figure 15) [96]. As a result, not only was quinine formation efficiently suppressed but also a high level of $o$-phenylene selectivity achieved. In a similar approach 
4-amino phenol was selectively polymerized by reversible blocking of the amino group via imine formation [97].

\section{Selected Examples}

There is an enormous amount of structurally diverse phenols, anilines and other aromatic monomers, which have been subjected to enzyme-initiated radical polymerization. A representative, but by far not exhaustive selection of the different monomers is given in Figures 16 and 17. For a detailed discussion about polymer properties and potential uses, the interested reader is referred to some excellent previous overviews [8-12].

Figure 16. Representative (and not exhaustive) selection of phenol monomers polymerized using oxidoreductases.
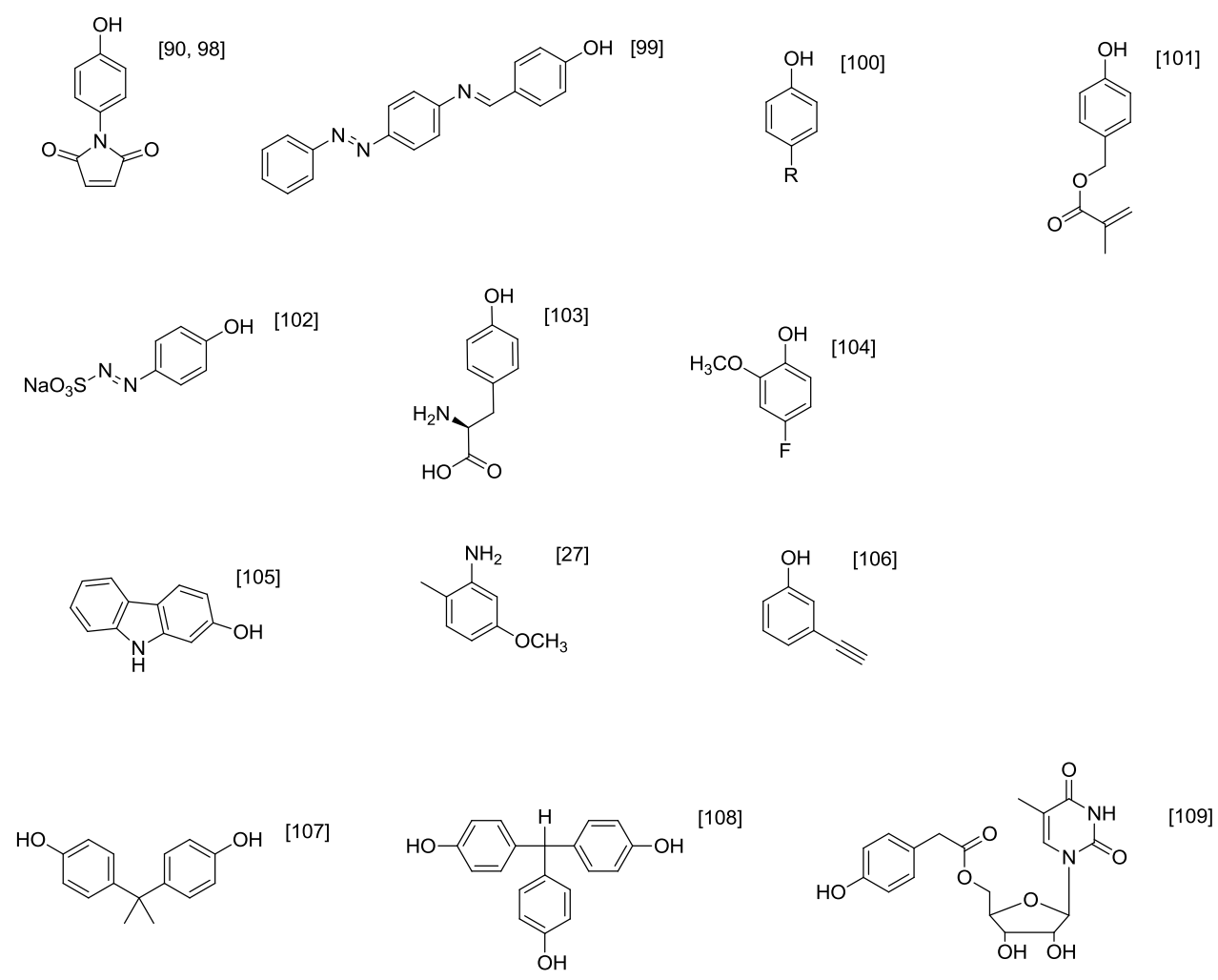

Figure 17. Representative selection of vinyl monomers polymerized by oxidoreductase catalysis.

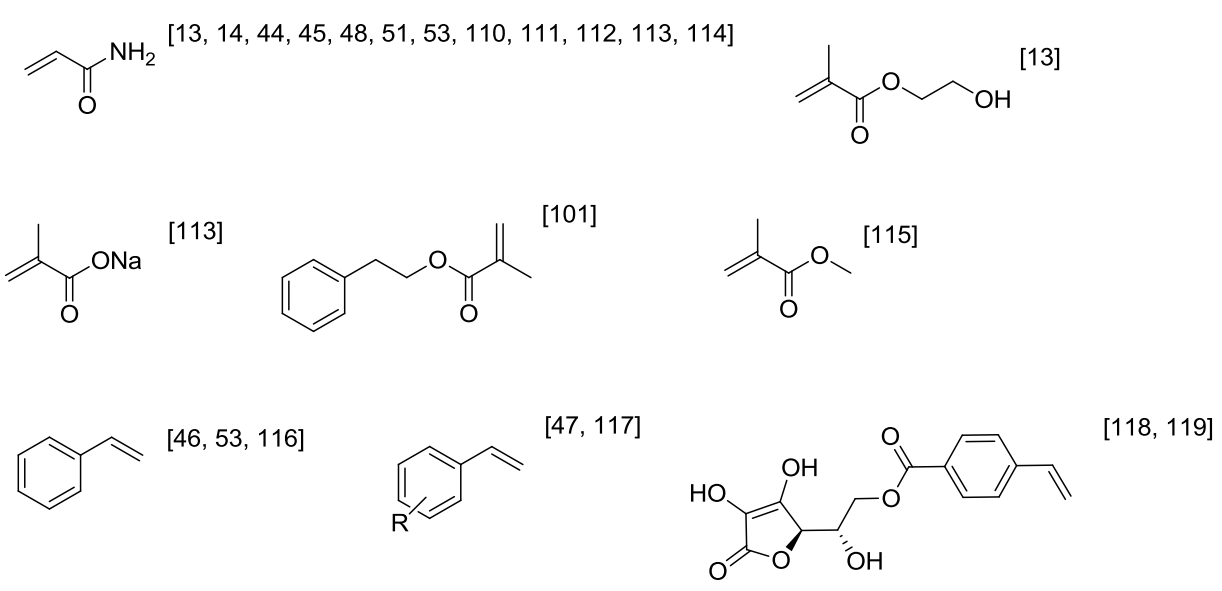




\subsection{Polyphenols}

Flavonoids represent a class of natural secondary metabolites that have found numerous applications in human health products. Especially their antioxidant and radical scavenging activity but also anti microbial properties make this product class interesting. The group around Kobayashi has investigated the production and properties of polymerized polyphenols [11]. Interestingly, in the majority of these examples, the antioxidant activity (and quite frequently also other health properties) are significantly increased as compared to the monomers. A unifying explanation for this observation is missing so far.

Early reports dealing with modified flavonids concern the direct laccase- and/or peroxidase-mediated polymerization of the monomers. More recently, oxidative conjugation to other polymers has gained considerable interest (Figure 18). Table 2 gives an overview over the polymeric products reported.

Table 2. Flanonoids polymerized for improved antioxidant activity.<smiles></smiles>

Catechin<smiles>O=c1ccc2cc(O[C@H]3O[C@H](CO)[C@@H](O)[C@H](O)[C@H]3O)c(O)cc2o1</smiles>

Esculin<smiles>C[C@H]1O[C@H](OC[C@H]2O[C@@H](Oc3c(-c4ccc(O)c(O)c4)oc4cc(O)cc(O)c4c3=O)[C@H](O)[C@H](O)[C@H]2O)[C@H](O)[C@@H](O)[C@H]1O</smiles>

Rutin<smiles>O=C(O[C@H]1Cc2c(O)cc(O)cc2O[C@@H]1c1cc(O)c(O)c(O)c1)c1cc(O)c(O)c(O)c1</smiles>

Epigallocatechin laccase

laccase

[120]

laccase

(122-1241

laccase

[127,128]

laccase

[129] 
Figure 18. Flavonoid-based antioxidant polymers obtained via (upper) radical polymerization of the monomers or (lower) Michael-coupling or Schiff-base formation of the quinone form of the flavonoids to $\left(\mathrm{NH}_{2}\right.$-containing) polymers.

\section{Oxidative polymerization}

= Flavonoid

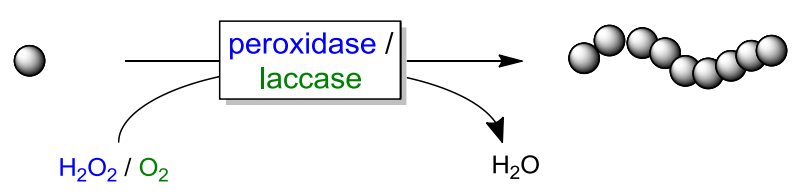

\section{Oxidative grafting on polymers}
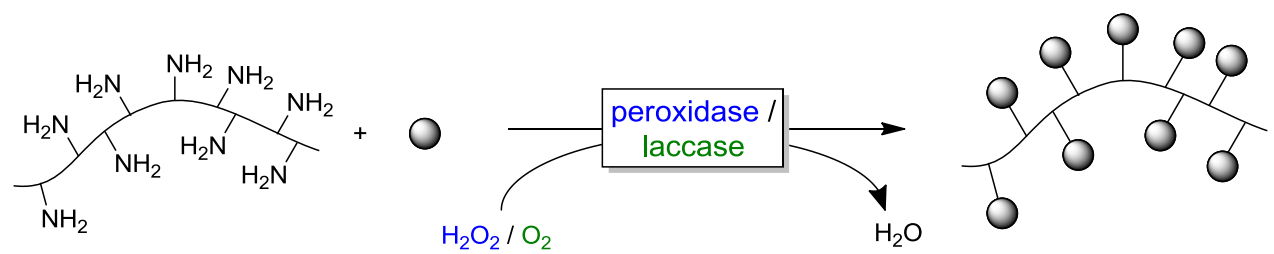

As mentioned above, the oxidative grafting of flavonoids to polymers is enjoying increased attention especially aiming at functionalized textiles or food applications [130].

One of the first examples for this was reported by Kobayashi and coworkers who oxidatively grafted poly(allylamine) with catechin (Figure 19) [131], which was followed up more recently by Rao and coworkers $[132,133]$.

Figure 19. Laccase-catalyzed oxidation of catechin combined with covalent grafting to poly(allylamine).<smiles>Oc1cc(O)c2c(c1)OC(c1ccc(O)c(O)c1)CC2O</smiles><smiles>CC(O)C1C(C)CCC1CO</smiles><smiles>O=C1C=CC(C2Oc3cc(O)cc(O)c3CC2O)C=C1</smiles>

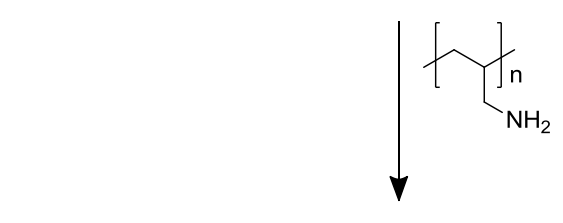<smiles>CC(C)CNc1cc(O)c(O)cc1C1Oc2cc(O)cc(O)c2CC1O</smiles>

Instead of poly(allylamine) also natural polymeric support can be used resulting in a composite with similarly superior antioxidant activity as compared to the catechin monomer. For example gelatin was 
grafted with catechin [134]. Wool can also be grafted e.g., with gallates resulting in composites with antioxidant and antimicrobial activity [135]. When using gallic acid esters, increased water repellence was achieved. Chitosan-composites with gallic acid (derivates) [136-139], ferulic acid [140], flavonoids [141] exhibit increased antioxidant activity. An interesting extension of this concept is to use amine-functionalized inorganic supports [142].

A practical application of this grafting technology may be in the textile and food industry yielding products with antimicrobial activity and modified rheological properties [130,138,139,143-146].

\subsection{Polymer Modification}

Oxidoreductase-initiated covalent linkage of phenols has also received considerable interest for the cross-linking of polymers to form biocompatible hydrogels. For example, proteins presenting tyrosine moieties at their surface can be gelled in the presence of laccases or peroxidases $/ \mathrm{H}_{2} \mathrm{O}_{2}$ (Figure 20) [147-150].

Figure 20. Schematic representation of crosslinked proteins via surface-located aromatic moieties.

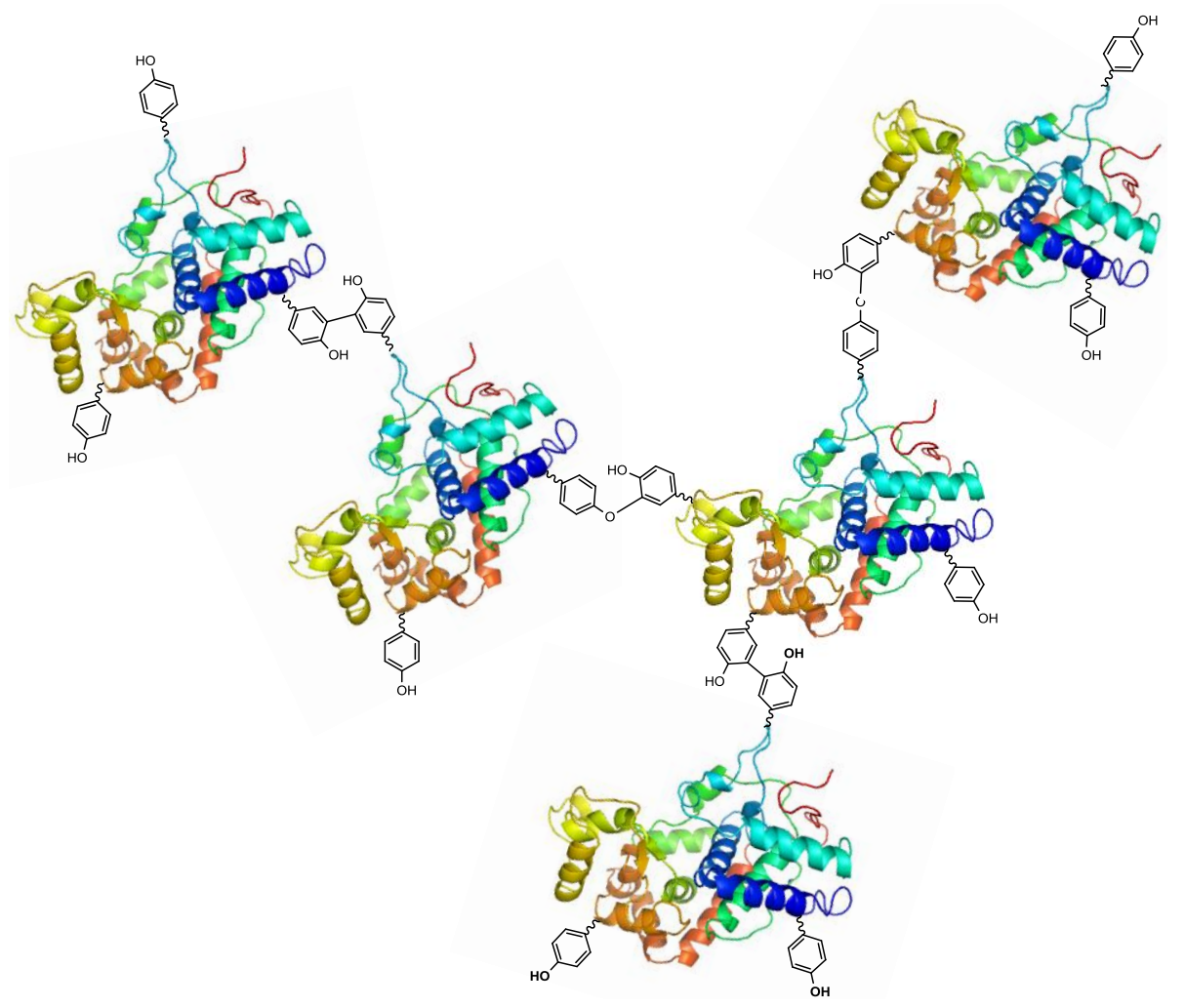

Next to proteins also natural polymers exhibiting phenolic side chains can be gelled enzymatically. For example pectins contain some ferulic acid which can be used for oxidative crosslinking of the pectin chains for irreversible gellation [151-153]. However, even if no phenolic side chain is present in the polymer, it may be introduced chemically. In that respect, tyramine has gained some popularity e.g., for the crosslinking of carboxymethyl cellulose [154], alginate [155], hyaluronic acid [156], dextran [157] or artificial polymers such as Tetronic [158].

$\mathrm{NH}_{2}$-containing polymers (e.g., chitosan) can be modified with phenolic carboxylic acids via amidation [159] or directly act in Michael-fashion on enzyme-generated quinones (Figure 21) [146,160]. 
For example, tyrosinases generate reactive quinones from phenols, which can react with chitosan [141,145,160,161]. Similarly, reactive quinones can be generated using laccases $[140,146]$ of peroxidases [136,139].

Figure 21. Modification of chitosan with enzyme-generated quinones.
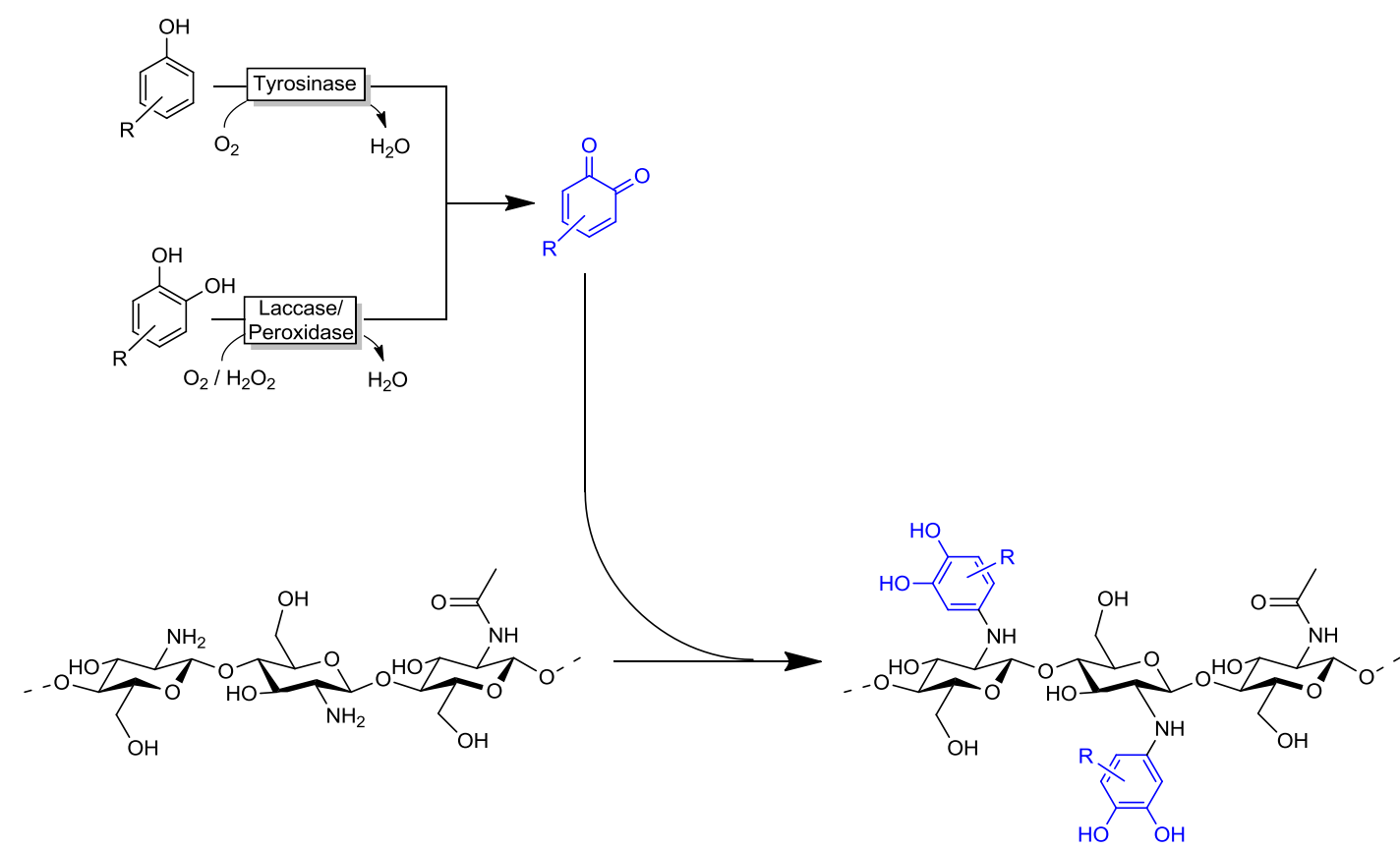

A very creative application of the system $\mathrm{HRP} / \mathrm{H}_{2} \mathrm{O}_{2} / \mathrm{Acac}$ for graft polymerization of acryl amide on starch was reported recently by Biswas and coworkers [114]. A biocatalytic alternative route to the established cerium(IV)-based routes to poly(acrylate)-grafted starch with applications as superabsorbers or performance additives in paper making or textile sizing was reported. Under non-optimized conditions grafting efficiencies of up to $65 \%$ are reported. The authors suggest covalent attachment of the poly(acrylamide) chain to the starch backbone via $\mathrm{H}$-abstraction at the glycosidic C-atom (Figure 22).

Figure 22. Proposed mechanism for the HRP-initiated poly(acrylamide)-grafting of starch.

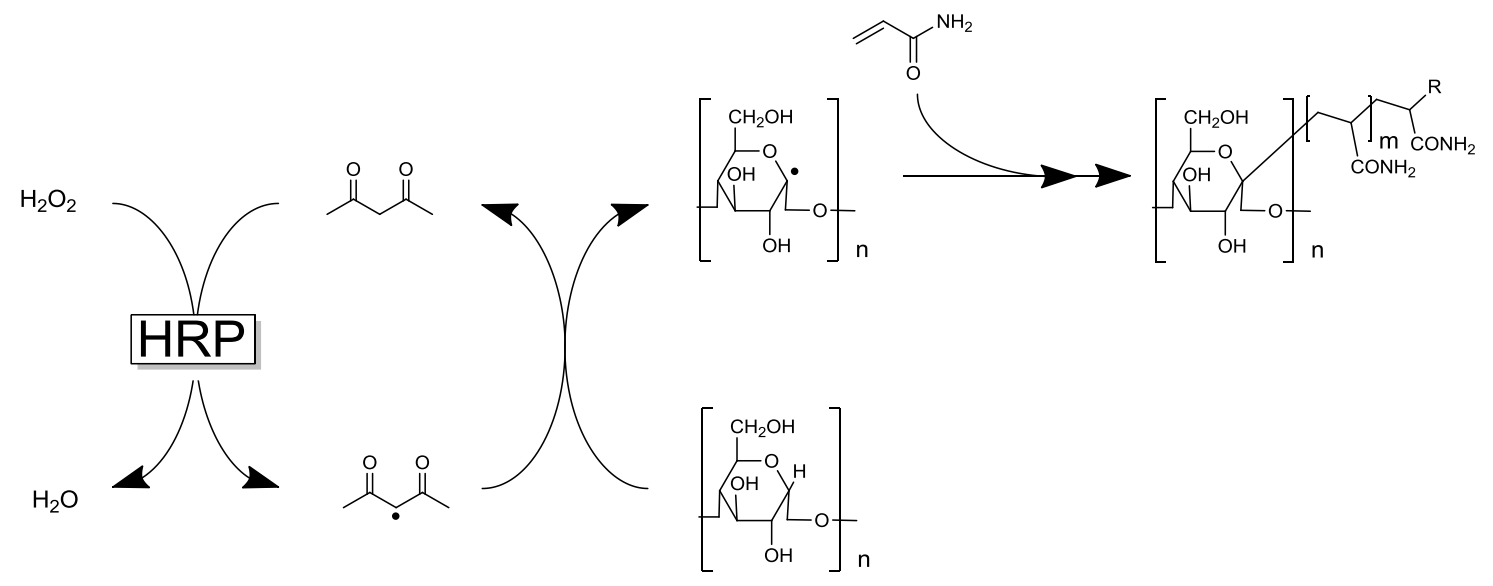

Poly(acrylamide) grafting onto lignin has been reported in the presence of organic hydroperoxides [162,163]. The proposed mechanism (Figure 23.) comprises laccase-catalyzed H-atom 
abstraction from phenolic lignin residues. The resulting phenoxy radicals interact with the peroxides generation alkoxy- and hydroperoxy-radicals, which are supposed to initiate the acrylamide polymerization process. Grafting of poly(acrylamide) onto lignin is proposed to occur through recombination of the respective radicals.

Figure 23. Proposed mechanism of laccase/hydroperoxide polymerization grafting of acrylamide onto lignin.

(1) Polymerization reaction

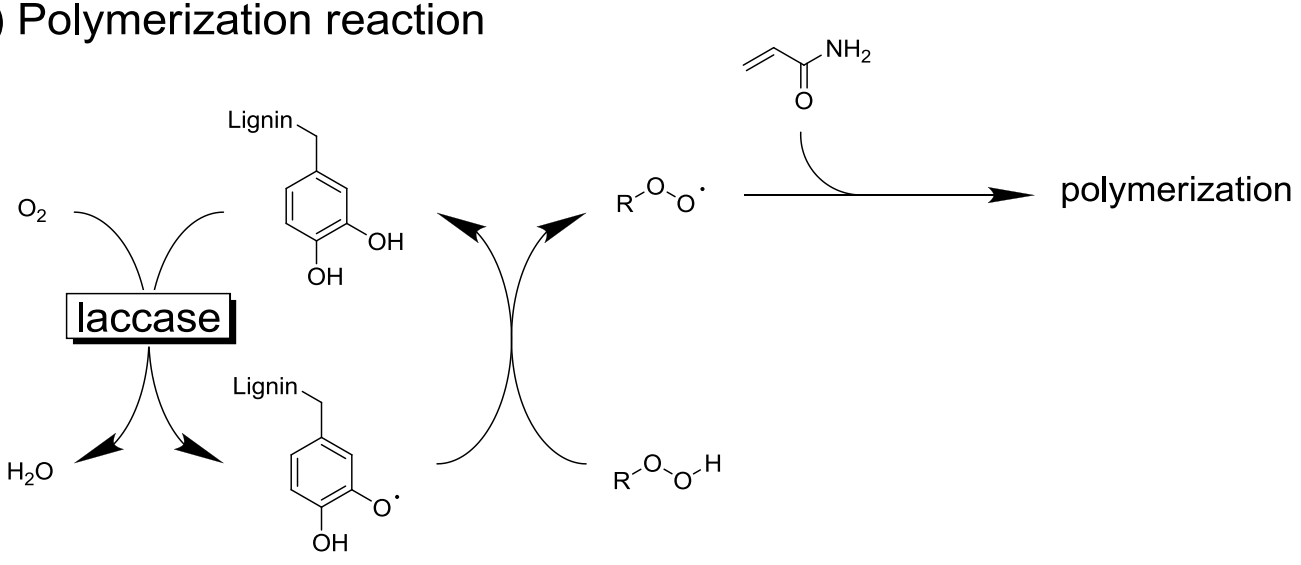

(2) Grafting

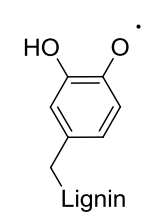

$$
+\mathrm{H}_{2} \mathrm{~N}_{\mathrm{NH}_{2}}^{\mathrm{O}}
$$

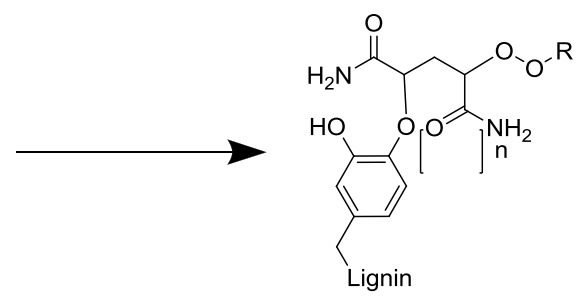

\subsection{Artificial Urushi}

Urushiols are a class of natural alkyl-substituted phenols and catechols (Figure 24), which in the presence of laccase can polymerize to form Urushi, a natural lacquer used e.g., in traditional Japanese artwork.

Due to its potential as 'fully renewable and benign' alternative to chemical formaldehyde-phenol resins, the enzymatic polymerization of urushiols has been thoroughly investigated by the Kobayashi group [164-167].

Figure 24. Structure of urushiol.<smiles>[R]c1cccc(O)c1O</smiles>

R:

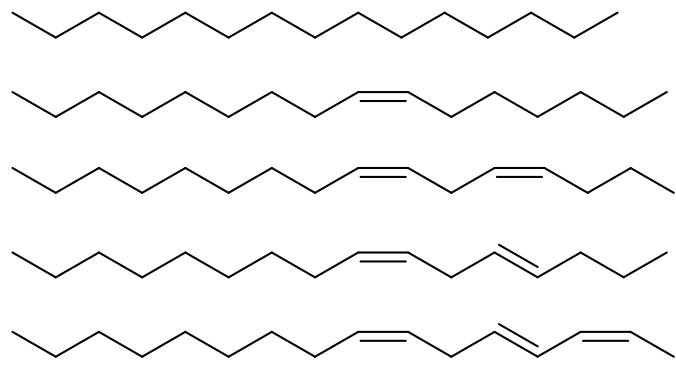


Synthetic, tailored urushiols have also been proposed by lipase-catalyzed acylation of benzylic $\mathrm{OH}$-groups followed by peroxidase- or laccase-initiated polymerization of the phenol/catechols moiety (Figure 25).

Figure 25. Bienzymatic formation of artificial urushi with tailored properties.<smiles>[X]c1cc(CO)ccc1O</smiles><smiles>CC1CCC(C)C1C</smiles><smiles>[R]C(=O)O</smiles><smiles>[R]C(=O)OCc1ccc(O)c([X])c1</smiles><smiles>CC1=C(C)[C@H](C)[C@@H](C)[C@H](C)OC1=O</smiles>

Cardanols are natural phenols structurally related to urusiols and likewise can be polymerized using laccases of peroxidases [32,33,168-170].

\subsection{Selected Examples for Chemoselective Polymerization}

One advantage of oxidoreductase-catalysis that is frequently mentioned is its high selectivity. As mentioned above, so far no examples of stereospecificity have been reported in enzyme initiated polymerization, and are not very likely to come up in the near future. However, there is a range of examples demonstrating chemoselective radical formation, which will be shortly outlined below.

The selective polymerization of bifunctional monomers containing vinyl and phenol moieties. Generally, laccases and peroxidases act on the phenol part selectively leading to vinyl-substituted poly(phenols) which then are available for further modification (Figure 26) [68,101,171].

A very nice example for the potential of biocatalysis as complementary tool to established chemocatalysis was reported using m-ethinylphenol as monomer [106]. Subjecting this compound to $\mathrm{HRP} / \mathrm{H}_{2} \mathrm{O}_{2}$, poly(phenol) formation was the only reaction observed wile leaving the ethinyl group untouched. In contrast, $\mathrm{Cu}^{\mathrm{I}}$ catalysts lead to dimerization via the ethinyl function (Figure 27).

Figure 26. Chemoselective polymerization of bifunctional (phenol/vinyl) monomer units using HRP.<smiles>C=C(C)C(=O)OCCc1ccc(O)cc1</smiles>
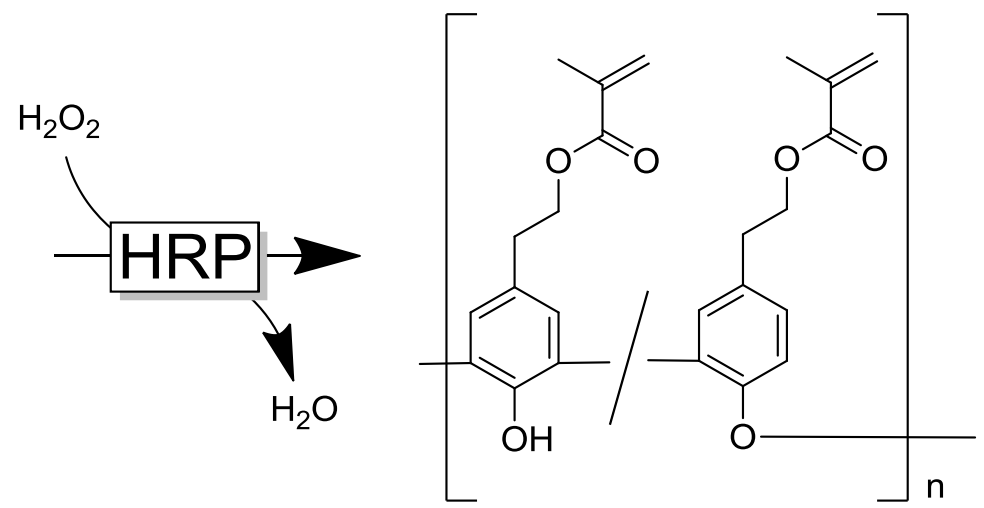
Figure 27. Complementary conversion of m-ethinylphenol using $\mathrm{HRP}$ or $\mathrm{Cu}^{\mathrm{I}}$.

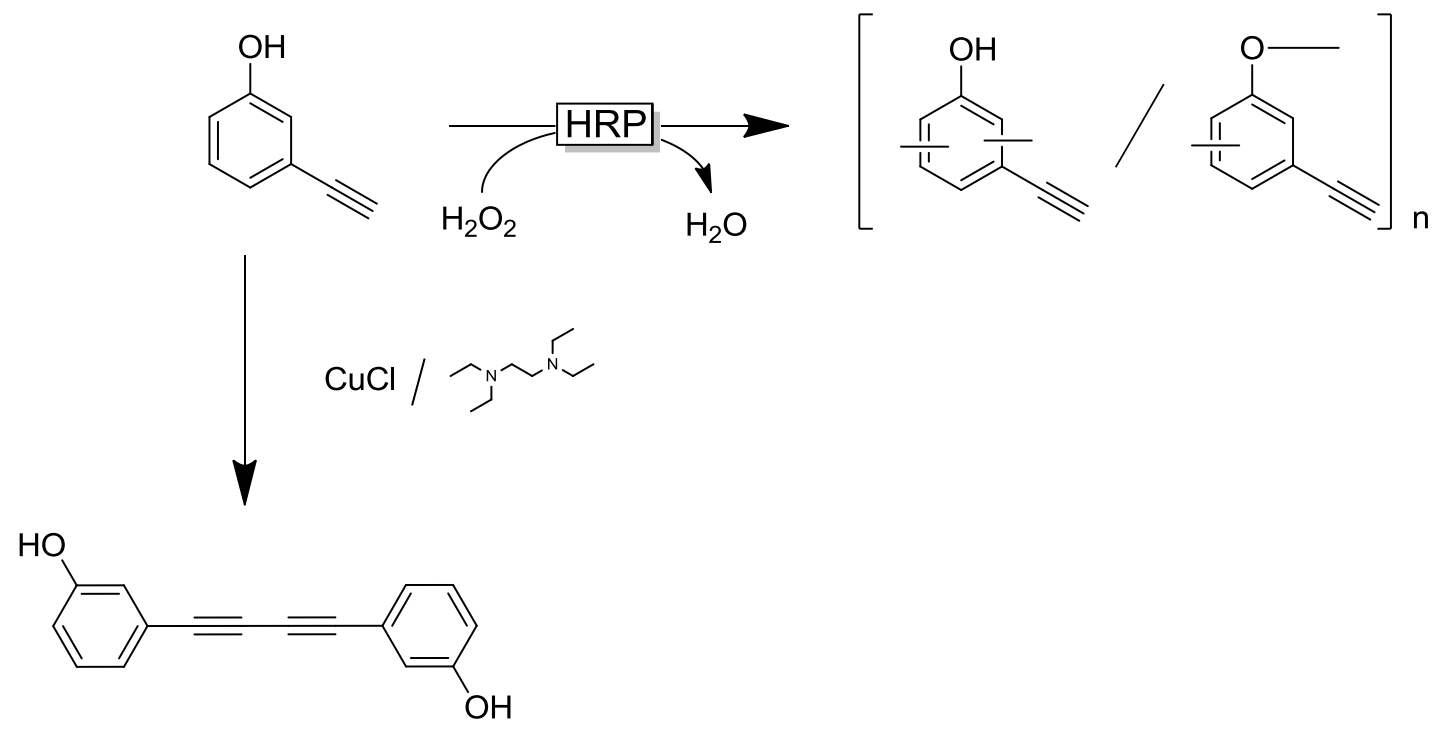

Another example for chemoselectivity of enzymatic polymerization was reported by Bilici et al. [172]. Here, an aldehyde-bearing catechols was polymerized enzymatically without oxidizing the aldehyde moiety.

\subsection{Phenol Detoxification}

A good portion of the laccase- and peroxidase literature deals with bioremediation and pollutant control [130,173-175]. The removal of phenolics is rather straightforward as these compounds are generally oxidized by the laccases or peroxidases directly [176]. In most of the cases, the detoxification mechanism is based on the formation of insoluble oligomeric or polymeric products which can then be removed by filtration.

Hence, various cresols and derivates [177] can be oxidatively polymerized and thereby reduced in toxicity. Likewise halophenols [178-182] bisphenol A, [183-185] various hormones and so-called endocrine disrupting compounds [186-188] or even TNT [189,190] have been reported. Non-phenolic compounds may be 'inactivated' using the LMS or PMS strategy [36,191-198].

\section{Conclusions}

Enzymatic reactions are enjoying increasing attention as alternatives to classical chemical routes. 'The hallmark of enzyme catalysis is its superior catalytic power and high selectivity under mild reaction conditions' [199]. Furthermore, enzyme catalysis generally exhibits high chemo-, regio-, and enantioselectivity. In the context of oxidoreductase initiated radical polymerizations these advantages come into play only to a limited extent. Mostly the role of the enzyme is confined to the generation of a starter radical. Thus, enzyme-initiated polymerizations comprise all characteristics of a classical chemical polymerization.

Admittedly, enzymatic routes offer various handles to control polymer weight with enzyme concentration being the most efficient one. Furthermore, enzymes are derived from renewable feedstock and therefore can be considered more benign than many classical initiators. Overall, 
enzyme-initiated polymerization represents a promising alternative approach to the established chemical routes. Implementation on industrial scale will not occur on a short-term due to cost limitations but may eventually result in significantly greener production routes (though a full life cycle analysis will be necessary as enzymatic reactions are not per se greener than their chemical counterparts). Furthermore, it represents another example that enzyme catalysis is not confined to its traditional playgrounds such as chiral molecules.

\section{Acknowledgments}

This work was supported by the Marie Curie ITN 'Biotrains' (grant agreement number 238531) and the Deutsche Bundesstiftung Umwelt, ChemBioTec (grant agreement number 13253).

\section{References}

1. Wenda, S.; Illner, S.; Mell, A.; Kragl, U. Industrial biotechnology-The future of green chemistry? Green Chem. 2011, 13, 3007-3047.

2. Hollmann, F.; Arends, I.W.C.E.; Buehler, K.; Schallmey, A.; Buhler, B. Enzyme-mediated oxidations for the chemist. Green Chem. 2011, 13, 226-265.

3. Hollmann, F.; Arends, I.W.C.E.; Holtmann, D. Enzymatic reductions for the chemist. Green Chem. 2011, 13, 2285-2313.

4. Kuhn, D.; Kholiq, M.A.; Heinzle, E.; Bühler, B.; Schmid, A. Intensification and economic and ecological assessment of a biocatalytic oxyfunctionalization process. Green Chem. 2010, 12, $815-827$.

5. Thum, O.; Oxenbøll, K.M. Biocatalysis: A sustainable process for production of cosmetic ingredients. In Proceedings of the International Federation of Societies of Cosmetic Chemists, IFSCC Congress 2006, Osaka, Japan, 16-19 October 2006.

6. Henderson, R.K.; Jiminez-Gonzalez, C.; Preston, C.; Constable, D.J.C.; Woodley, J.M. EHS \& LCA assessment for 7-ACA synthesis A case study for comparing biocatalytic \& chemical synthesis. Ind. Biotechnol. 2008, 4, 180-192.

7. Sheldon, R.A. E factors, green chemistry and catalysis: An odyssey. Chem. Commun. 2008, 3352-3365.

8. Kobayashi, S.; Makino, A. Enzymatic polymer synthesis: An opportunity for green polymer chemistry. Chem. Rev. 2009, 109, 5288-5353.

9. Uyama, H.; Kobayashi, S.; Ritter, H.; Kaplan, D. Enzymatic synthesis and properties of polymers from polyphenols. In Enzyme-Catalyzed Synthesis of Polymers; Springer: Berlin, Germany and Heidelberg, Germany, 2006; Volume 194, pp. 51-67.

10. Singh, A.; Kaplan, D.L. Enzyme-based vinyl polymerization. J. Polym. Environ. 2002, 10, 85-91.

11. Uyama, H. Artificial polymeric flavonoids: Synthesis and applications. Macromol. Biosci. 2007, 7, 410-422.

12. Reihmann, M.; Ritter, H. Synthesis of phenol polymers using peroxidases. In Enzyme-Catalyzed Synthesis of Polymers; Kobayashi, S., Ritter, H., Kaplan, D., Eds.; Springer-Verlag: Berlin, Germany, 2006; Volume 194, pp. 1-49. 
13. Derango, R.; Chiang, L.-C.; Dowbenko, R.; Lasch, J. Enzyme-mediated polymerization of acrylic monomers. Biotechnol. Technol. 1992, 6, 523-526.

14. Tsujimoto, T.; Uyama, H.; Kobayashi, S. Polymerization of vinyl monomers using oxidase catalysts. Macromol. Biosci. 2001, 1, 228-232.

15. Kausaite, A.; Ramanaviciene, A.; Ramanavicius, A. Polyaniline synthesis catalysed by glucose oxidase. Polymer 2009, 50, 1846-1851.

16. Hofrichter, M.; Ullrich, R.; Pecyna, M.J.; Liers, C.; Lundell, T. New and classic families of secreted fungal heme peroxidases. Appl. Microbiol. Biotechnol. 2010, 87, 871-897.

17. Van Rantwijk, F.; Sheldon, R.A. Selective oxygen transfer catalysed by heme peroxidases: Synthetic and mechanistic aspects. Curr. Opin. Biotechnol. 2000, 11, 554-564.

18. Hanson, R.L.; Howell, J.M.; LaPorte, T.L.; Donovan, M.J.; Cazzulino, D.L.; Zannella, V.; Montana, M.A.; Nanduri, V.B.; Schwarz, S.R.; Eiring, R.F.; et al. Synthesis of allysine ethylene acetal using phenylalanine dehydrogenase from Thermoactinomyces intermedius. Enzym. Microb. Technol. 2000, 26, 348-358.

19. Valderrama, B.; Ayala, M.; Vazquez-Duhalt, R. Suicide inactivation of peroxidases and the challenge of engineering more robust enzymes. Chem. Biol. 2002, 9, 555-565.

20. Hiner, A.N.P.; Hernández-Ruiz, J.; Williams, G.A.; Arnao, M.B.; García-Cánovas, F.; Acosta, M. Catalase-like oxygen production by horseradish peroxidase must predominantly be an enzyme-catalyzed reaction. Arch. Biochem. Biophys. 2001, 392, 295-302.

21. Collinson, E.; Dainton, F.S.; McNaughton, G.S. The polymerization of acrylamide in aqueous solution. Part 1.The X- and $\gamma$-ray initiated reaction. Trans. Faraday Soc. 1957, 53, 476-488.

22. Hollmann, F.; Arends, I.W.C.E.; Buehler, K. Biocatalytic redox reactions for organic synthesis: Nonconventional regeneration methods. ChemCatChem 2010, 2, 762-782.

23. Churakova, E.; Kluge, M.; Ullrich, R.; Arends, I.; Hofrichter, M.; Hollmann, F. Specific photobiocatalytic oxyfunctionalization reactions. Angew. Chem. Int. Ed. 2011, 50, 10716-10719.

24. Perez, D.I.; Mifsud Grau, M.; Arends, I.W.C.E.; Hollmann, F. Visible light-driven and chloroperoxidase-catalyzed oxygenation reactions. Chem. Commun. 2009, 6848-6850.

25. Uyama, H.; Kurioka, H.; Kobayashi, S. Novel bienzymatic catalysis system for oxidative polymerization of phenols. Polym. J. 1997, 29, 190-192.

26. Taboada-Puig, R.; Junghanns, C.; Demarche, P.; Moreira, M.T.; Feijoo, G.; Lema, J.M.; Agathos, S.N. Combined cross-linked enzyme aggregates from versatile peroxidase and glucose oxidase: Production, partial characterization and application for the elimination of endocrine disruptors. Bioresour. Technol. 2011, 102, 6593-6599.

27. Kim, S.C.; Huh, P.; Kumar, J.; Kim, B.; Lee, J.O.; Bruno, F.F.; Samuelson, L.A. Synthesis of polyaniline derivatives via biocatalysis. Green Chem. 2007, 9, 44-48.

28. Kunamneni, A.; Camarero, S.; Garcia-Burgos, C.; Plou, F.; Ballesteros, A.; Alcalde, M. Engineering and applications of fungal laccases for organic synthesis. Microb. Cell Factories 2008, 7, doi:10.1186/1475-2859-7-32.

29. Witayakran, S.; Ragauskas, A.J. Synthetic applications of laccase in green chemistry. Adv. Synth. Catal. 2009, 351, 1187-1209.

30. Riva, S. Laccases: Blue enzymes for green chemistry. Trends Biotechnol. 2006, 24, 219-226. 
31. Cañas, A.I.; Camarero, S. Laccases and their natural mediators: Biotechnological tools for sustainable eco-friendly processes. Biotechnol. Adv. 2010, 28, 694-705.

32. Won, K.; Kim, Y.H.; An, E.S.; Lee, Y.S.; Song, B.K. Horseradish peroxidase-catalyzed polymerization of cardanol in the presence of redox mediators. Biomacromolecules 2004, 5, 1-4.

33. Chelikani, R.; Kim, Y.H.; Yoon, D.Y.; Kim, D.S. Enzymatic polymerization of natural anacardic acid and antibiofouling effects of polyanacardic acid coatings. Appl. Biochem. Biotechnol. 2009, 157, 263-277.

34. Song, H.K.; Palmore, G.T.R. Conductive polypyrrole via enzyme catalysis. J. Phys. Chem. B 2005, 109, 19278-19287.

35. Cruz-Silva, R.; Amaro, E.; Escamilla, A.; Nicho, M.E.; Sepulveda-Guzman, S.; Arizmendi, L.; Romero-Garcia, J.; Castillon-Barraza, F.F.; Farias, M.H. Biocatalytic synthesis of polypyrrole powder, colloids, and films using horseradish peroxidase. J. Colloid Interface Sci. 2008, 328, 263-269.

36. Eibes, G.; Debernardi, G.; Feijoo, G.; Moreira, M.T.; Lema, J.M. Oxidation of pharmaceutically active compounds by a ligninolytic fungal peroxidase. Biodegradation 2011, 22, 539-550.

37. Kim, S.; Silva, C.; Evtuguin, D.V.; Gamelas, J.A.F.; Cavaco-Paulo, A. Polyoxometalate/laccase-mediated oxidative polymerization of catechol for textile dyeing. Appl. Microbiol. Biotechnol. 2011, 89, 981-987.

38. Nagarajan, S.; Kumar, J.; Bruno, F.F.; Samuelson, L.A.; Nagarajan, R. Biocatalytically synthesized poly(3,4-ethylenedioxythiophene). Macromolecules 2008, 41, 3049-3052.

39. Sigg, S.J.; Seidi, F.; Renggli, K.; Silva, T.B.; Kali, G.; Bruns, N. Horseradish peroxidase as a catalyst for atom transfer radical polymerization. Macromol. Rapid Commun. 2011, 32, 1710-1715.

40. Ng, Y.H.; di Lena, F.; Chai, C.L.L. PolyPEGA with predetermined molecular weights from enzyme-mediated radical polymerization in water. Chem. Commun. 2011, 47, 6464-6466.

41. Ng, Y.H.; di Lena, F.; Chai, C.L.L. Metalloenzymatic radical polymerization using alkyl halides as initiators. Polym. Chem. 2011, 2, 589-594.

42. Tsarevsky, N.V.; Matyjaszewski, K. "Green" atom transfer radical polymerization: From process design to preparation of well-defined environmentally friendly polymeric materials. Chem. Rev. 2007, 107, 2270-2299.

43. Rodrigues, A.P.; da Fonseca, L.M.; de Faria Oliveira, O.M.; Brunetti, I.L.; Ximenes, V.F. Oxidation of acetylacetone catalyzed by horseradish peroxidase in the absence of hydrogen peroxide. Biochim. Biophys. Acta 2006, 1760, 1755-1761.

44. Durand, A.; Lalot, T.; Brigodiot, M.; Maréchal, E. Enzyme-mediated radical initiation of acrylamide polymerization: Main characteristics of molecular weight control. Polymer 2001, 42, $5515-5521$.

45. Hollmann, F.; Gumulya, Y.; Toelle, C.; Liese, A.; Thum, O. Evaluation of the laccase from myceliophthora thermophila as industrial biocatalyst for polymerization reactions. Macromolecules 2008, 41, 8520-8524.

46. Qi, G.G.; Jones, C.W.; Schork, F.J. Enzyme-initiated miniemulsion polymerization. Biomacromolecules 2006, 7, 2927-2930. 
47. Singh, A.; Ma, D.; Kaplan, D.L. Enzyme-mediated free radical polymerization of styrene. Biomacromolecules 2000, 1, 592-596.

48. Teixeira, D.; Lalot, T.; Brigodiot, M.; Marechal, E. $\beta$-diketones as key compounds in free-radical polymerization by enzyme-mediated initiation. Macromolecules 1999, 32, 70-72.

49. Baader, W.J.; Bohne, C.; Cilento, G.; Dunford, H.B. Peroxidase-catalyzed formation of triplet acetone and chemiluminescence from isobutyraldehyde and molecular oxygen. J. Biol. Chem. 1985, 260, 10217-10225.

50. Parravano, G. Chain reactions induced by enzymic systems. J. Am. Chem. Soc. 1951, 73, 183-184.

51. Emery, O.; Lalot, T.; Brigodiot, M.; Maréchal, E. Free-Radical polymerization of acrylamide by horseradish peroxidase-mediated initiation. J. Polym. Sci. A 1997, 35, 3331-3333.

52. Ikeda, R.; Tanaka, H.; Uyama, H.; Kobayashi, S. Laccase-catalyzed polymerization of acrylamide. Macromol. Rapid Commun. 1998, 19, 423-425.

53. Villarroya, S.; Thurecht, K.J.; Howdle, S.M. HRP-mediated inverse emulsion polymerisation of acrylamide in supercritical carbon dioxide. Green Chem. 2008, 10, 863-867.

54. Nieto, M.; Nardecchia, S.; Peinado, C.; Catalina, F.; Abrusci, C.; Gutierrez, M.C.; Ferrer, M.L.; del Monte, F. Enzyme-induced graft polymerization for preparation of hydrogels: Synergetic effect of laccase-immobilized-cryogels for pollutants adsorption. Soft Matter 2010, 6, 3533-3540.

55. Ayyagari, M.S.R.; Kaplan, D.L.; Chatterjee, S.; Walker, J.E.; Akkara, J.A. Solvent effects in horseradish peroxidase-catalyzed polyphenol synthesis. Enzym. Microb. Technol. 2002, 30, 3-9.

56. Akkara, J.A.; Ayyagari, M.S.R.; Bruno, F.F. Enzymatic synthesis and modification of polymers in nonaqueous solvents. Trends Biotechnol. 1999, 17, 67-73.

57. Dordick, J.S.; Marletta, M.A.; Klibanov, A.M. Polymerization of phenols catalyzed by peroxidase in nonaqueous media. Biotechnol. Bioeng. 1987, 30, 31-36.

58. Oguchi, T.; Tawaki, S.; Uyama, H.; Kobayashi, S. Soluble polyphenol. Macromol. Rapid Commun. 1999, 20, 401-403.

59. Mita, N.; Maruichi, N.; Tonami, H.; Nagahata, R.; Tawaki, S.; Uyama, H.; Kobayashi, S. Enzymatic oxidative polymerization of $p$-t-butylphenol and characterization of the product polymer. Bull. Chem. Soc. Jpn. 2003, 76, 375-379.

60. Mita, N.; Tawaki, S.; Uyama, H.; Kobayashi, S. Structural control in enzymatic oxidative polymerization of phenols with varying the solvent and substituent nature. Chem. Lett. 2002, 402-403.

61. Mita, N.; Tawaki, S.; Uyama, H.; Kobayashi, S. Precise structure control of enzymatically synthesized polyphenols. Bull. Chem. Soc. Jpn. 2004, 77, 1523-1527.

62. Mita, N.; Tawaki, S.-I.; Uyama, H.; Kobayashi, S. Laccase-catalyzed oxidative polymerization of phenols. Macromol. Biosci. 2003, 3, 253-257.

63. Sgalla, S.; Fabrizi, G.; Cacchi, S.; Macone, A.; Bonamore, A.; Boffi, A. Horseradish peroxidase in ionic liquids: Reactions with water insoluble phenolic substrates. J. Mol. Catal. B 2007, 44, 144-148.

64. Eker, B.; Zagorevski, D.; Zhu, G.Y.; Linhardt, R.J.; Dordick, J.S. Enzymatic polymerization of phenols in room-temperature ionic liquids. J. Mol. Catal. B 2009, 59, 177-184. 
65. Zaragoza-Gasca, P.; Villamizar-Gálvez, O.J.; García-Arrazola, R.; Gimeno, M.; Bárzana, E. Use of ionic liquid for the enzyme-catalyzed polymerization of phenols. Polym. Adv. Technol. 2010, 21, 454-456.

66. Rumbau, V.; Marcilla, R.; Ochoteco, E.; Pomposo, J.A.; Mecerreyes, D. Ionic liquid immobilized enzyme for biocatalytic synthesis of conducting polyaniline. Macromolecules 2006, 39, 8547-8549.

67. Nakamura, R.; Matsushita, Y.; Umemoto, K.; Usuki, A.; Fukushima, K. Enzymatic polymerization of coniferyl alcohol in the presence of cyclodextrins. Biomacromolecules 2006, 7, 1929-1934.

68. Reihmann, M.H.; Ritter, H. Oxidative oligomerization of cyclodextrin-complexed bifunctional phenols catalyzed by horseradish peroxidase in water. Macromol. Chem. Phys. 2000, 201, 798-804.

69. Mita, N.; Tawaki, S.; Uyama, H.; Kobayashi, S. Enzymatic oxidative polymerization of phenol in an aqueous solution in the presence of a catalytic amount of cyclodextrin. Macromol. Biosci. 2002, 2, 127-130.

70. Dordick, J.S.; Marletta, M.A.; Klibanov, A.M. Peroxidase depolymerize lignin in organic media but not in water. Proc. Natl. Acad. Sci. USA 1986, 83, 6255-6257.

71. Angerer, P.S.; Studer, A.; Witholt, B.; Li, Z. Oxidative polymerization of a substituted phenol with ion-paired horseradish peroxidase in an organic solvent. Macromolecules 2005, 38, $6248-6250$.

72. Oshima, T.; Sato, M.; Shikaze, Y.; Ohto, K.; Inoue, K.; Baba, Y. Enzymatic polymerization of $o$-phenylendiamine with cytochrome $c$ activated by a calixarene derivative in organic media. Biochem. Eng. J. 2007, 35, 66-70.

73. Walde, P.; Guo, Z.W. Enzyme-catalyzed chemical structure-controlling template polymerization. Soft Matter 2011, 7, 316-331.

74. Samuelson, L.A.; Anagnostopoulos, A.; Alva, K.S.; Kumar, J.; Tripathy, S.K. Biologically derived conducting and water soluble polyaniline. Macromolecules 1998, 31, 4376-4378.

75. Nabid, M.R.; Taheri, S.S.; Sedghi, R.; Rezaei, S.J.T. Synthesis and characterization of chemiluminescent conducting polyluminol via biocatalysis. Macromol. Res. 2011, 19, 280-285.

76. Nabid, M.R.; Sedghi, R.; Entezami, A.A. Enzymatic oxidation of alkoxyanilines for preparation of conducting polymers. J. Appl. Polym. Sci. 2007, 103, 3724-3729.

77. Huh, P.; Kim, S.C.; Kim, Y.; Wang, Y.; Singh, J.; Kumar, J.; Samuelson, L.A.; Kim, B.S.; Jo, N.J.; Lee, J.O. Optical and electrochemical detection of saccharides with poly(aniline-co-3am nobenzeneboronic acid) prepared from enzymatic polymerization. Biomacromolecules 2007, 8, 3602-3607.

78. Karamyshev, A.V.; Shleev, S.V.; Koroleva, O.V.; Yaropolov, A.I.; Sakharov, I.Y. Laccase-catalyzed synthesis of conducting polyaniline. Enzym. Microb. Technol. 2003, 33, $556-564$.

79. Tewari, A.; Kokil, A.; Ravichandran, S.; Nagarajan, S.; Bouldin, R.; Samuelson, L.A.; Nagarajan, R.; Kumar, J. Soybean peroxidase catalyzed enzymatic synthesis of pyrrole/EDOT copolymers. Macromol. Chem. Phys. 2010, 211, 1610-1617.

80. Vasil'eva, I.; Morozova, O.; Shumakovich, G.; Yaropolov, A. Synthesis of electroconductive polyaniline using immobilized laccase. Appl. Biochem. Microbiol. 2009, 45, 27-30. 
81. Nagarajan, R.; Tripathy, S.; Kumar, J.; Bruno, F.F.; Samuelson, L. An enzymatically synthesized conducting molecular complex of polyaniline and poly(vinylphosphonic acid). Macromolecules 2000, 33, 9542-9547.

82. Thiyagarajan, M.; Samuelson, L.A.; Kumar, J.; Cholli, A.L. Helical conformational specificity of enzymatically synthesized water-soluble conducting polyaniline nanocomposites. J. Am. Chem. Soc. 2003, 125, 11502-11503.

83. Nagarajan, R.; Liu, W.; Kumar, J.; Tripathy, S.K.; Bruno, F.F.; Samuelson, L.A. Manipulating DNA conformation using intertwined conducting polymer chains. Macromolecules 2001, 34, 3921-3927.

84. Ma, Y.; Zhang, J.; Zhang, G.; He, H. Polyaniline nanowires on si surfaces fabricated with DNA templates. J. Am. Chem. Soc. 2004, 126, 7097-7101.

85. Streltsov, A.V.; Morozova, O.V.; Arkharova, N.A.; Klechkovskaya, V.V.; Staroverova, I.N.; Shumakovich, G.P.; Yaropolov, A.I. Synthesis and characterization of conducting polyaniline prepared by laccase-catalyzed method in sodium dodecylbenzenesulfonate micellar solutions. J. Appl. Polym. Sci. 2009, 114, 928-934.

86. Streltsov, A.V.; Shumakovich, G.P.; Morozova, O.V.; Gorbacheva, M.A.; Yaropolov, A.I. Micellar laccase-catalyzed synthesis of electroconductive polyaniline. Appl. Biochem. Microbiol. 2008, 44, 264-270.

87. Bouldin, R.; Ravichandran, S.; Kokil, A.; Garhwal, R.; Nagarajan, S.; Kumar, J.; Bruno, F.F.; Samuelson, L.A.; Nagarajan, R. Synthesis of polypyrrole with fewer structural defects using enzyme catalysis. Synth. Met. 2011, 161, 1611-1617.

88. Kim, Y.J.; Shibata, K.; Uyama, H.; Kobayashi, S. Synthesis of ultrahigh molecular weight phenolic polymers by enzymatic polymerization in the presence of amphiphilic triblock copolymer in water. Polymer 2008, 49, 4791-4795.

89. Kim, Y.J.; Uyama, H.; Kobayashi, S. Enzymatic template polymerization of phenol in the presence of water-soluble polymers in an aqueous medium. Polym. J. 2004, 36, 992-998.

90. Kim, Y.J.; Uyama, H.; Kobayashi, S. Peroxidase-catalyzed oxidative polymerization of phenol with a nonionic polymer surfactant template in water. Macromol. Biosci. 2004, 4, 497-502.

91. Kim, Y.J.; Uyama, H.; Kobayashi, S. Regioselective synthesis of poly(phenylene) as a complex with poly(ethylene glycol) by template polymerization of phenol in water. Macromolecules $\mathbf{2 0 0 3}$, 36, 5058-5060.

92. Bruno, F.F.; Nagarajan, R.; Stenhouse, P.; Yang, K.; Kumar, J.; Tripathy, S.K.; Samuelson, L.A. Polymerization of water-soluble conductive polyphenol using horseradish peroxidase. J. Macromol. Sci. Pure Appl. Chem. 2001, 38, 1417-1426.

93. Peng, Y.; Liu, H.W.; Zhang, X.Y.; Li, Y.S.; Liu, S.Y. CNT templated regioselective enzymatic polymerization of phenol in water and modification of surface of MWNT thereby. J. Polym. Sci. Pol. Chem. 2009, 47, 1627-1635.

94. Xu, P.; Uyama, H.; Whitten, J.E.; Kobayashi, S.; Kaplan, D.L. Peroxidase-catalyzed in situ polymerization of surface orientated caffeic acid. J. Am. Chem. Soc. 2005, 127, 11745-11753.

95. Ikeda, R.; Sugihara, J.; Uyama, H.; Kobayashi, S. Enzymatic oxidative polymerization of 4-hydroxybenzoic acid derivatives to poly(phenylene oxide)s. Polym. Int. 1998, 47, 295-301. 
96. Wang, P.; Martin, B.D.; Parida, S.; Rethwisch, D.G.; Dordick, J.S. Multienzymic synthesis of poly(hydroquinone) for use as a redox polymer. J. Am. Chem. Soc. 1995, 117, 12885-12886.

97. Reihmann, M.H.; Ritter, H. Regioselective HRP-catalyzed polymerization of 4-amino-phenol. J. Macromol. Sci. Pure Appl. Chem. 2002, A39, 1369-1382.

98. Reihmann, M.H.; Ritter, H. Oxidative copolymerization of para-functionalized phenols catalyzed by horseradish peroxidase and thermocrosslinking via Diels-Alder and $(1+3)$ cycloaddition. Macromol. Biosci. 2001, 1, 170-176.

99. Turac, E.; Sahmetlioglu, E. Oxidative polymerization of 4-[(4-phenylazo-phenyimino)-methyl]phenol catalyzed by horseradish peroxidase. Synth. Met. 2010, 160, 169-172.

100. Uyama, H.; Kurioka, H.; Sugihara, J.; Komatsu, I.; Kobayashi, S. Oxidative polymerization of p-alkylphenols catalyzed by horseradish peroxidase. J. Polym. Sci. Pol. Chem. 1997, 35, 1453-1459.

101. Uyama, H.; Lohavisavapanich, C.; Ikeda, R.; Kobayashi, S. Chemoselective polymerization of a phenol derivative having a methacryl group by peroxidase catalyst. Macromolecules 1998, 31, 554-556.

102. Robert, J.P.; Uyama, H.; Kobayashi, S.; Jordan, R.; Nuyken, O. First diazosulfonate homopolymer by enzymatic polymerization. Macromol. Rapid Commun. 2003, 24, 185-189.

103. Fukuoka, T.; Tachibana, Y.; Tonami, H.; Uyama, H.; Kobayashi, S. Enzymatic polymerization of tyrosine derivatives. Peroxidase- and protease-catalyzed synthesis of poly(tyrosine)s with different structures. Biomacromolecules 2002, 3, 768-774.

104. Zaragoza-Gasca, P.; Gimeno, M.; Hernandez, J.M.; Barzana, E. Novel photoconductive polyfluorophenol synthesized by an enzyme. J. Mol. Catal. B 2011, 72, 25-27.

105. Bilici, A.; Kaya, Ä.; Yildirim, M.; Dogan, F. Enzymatic polymerization of hydroxy-functionalized carbazole monomer. J. Mol. Catal. B 2010, 64, 89-95.

106. Tonami, H.; Uyama, H.; Kobayashi, S.; Fujita, T.; Taguchi, Y.; Osada, K. Chemoselective oxidative polymerization of m-ethynylphenol by peroxidase catalyst to a new reactive polyphenol. Biomacromolecules 2000, 1, 149-151.

107. Kim, Y.H.; An, E.S.; Park, S.Y.; Lee, J.O.; Kim, J.H.; Song, B.K. Polymerization of bisphenol a using Coprinus cinereus peroxidase (CiP) and its application as a photoresist resin. J. Mol. Catal. B 2007, 44, 149-154.

108. Kadota, J.; Fukuoka, T.; Uyama, H.; Hasegawa, K.; Kobayashi, S. New positive-type photoresists based on enzymatically synthesized polyphenols. Macromol. Rapid Commun. 2004, 25, 441-444.

109. Wang, P.; Dordick, J.S. Enzymatic synthesis of unique thymidine-containing polyphenols. Macromolecules 1998, 31, 941-943.

110. Durand, A.; Lalot, T.; Brigodiot, M.; Maréchal, E. Enzyme-mediated initiation of acrylamide polymerization: Reaction mechanism. Polymer 2000, 41, 8183-8192.

111. Lalot, T.; Brigodiot, M.; Maréchal, E. A kinetic approach to acrylamide radical polymerization by horse radish peroxidase-mediated initiation. Polym. Int. 1999, 48, 288-292.

112. Zhao, Q.; Sun, J.Z.; Ren, H.; Zhou, Q.Y.; Lin, Q.C. Horseradish peroxidase immobilized in macroporous hydrogel for acrylamide polymerization. J. Polym. Sci. Pol. Chem. 2008, 46, 2222-2232. 
113. Kalra, B.; Gross, R.A. HRP-mediated polymerizations of acrylamide and sodium acrylate. Green Chem. 2002, 4, 174-178.

114. Shogren, R.L.; Willett, J.L.; Biswas, A. HRP-mediated synthesis of starch-polyacrylamide graft copolymers. Carbohyd. Polym. 2009, 75, 189-191.

115. Kalra, B.; Gross, R.A. Horseradish peroxidase mediated free radical polymerization of methyl methacrylate. Biomacromolecules 2000, 1, 501-505.

116. Shan, J.; Kitamura, Y.; Yoshizawa, H. Emulsion polymerization of styrene by horseradish peroxidase-mediated initiation. Colloid Polym. Sci. 2005, 284, 108-111.

117. Singh, A.; Roy, S.; Samuelson, L.; Bruno, F.; Nagarajan, R.; Kumar, J.; John, V.; Kaplan, D.L. Peroxidase, hematin, and pegylated-hematin catalyzed vinyl polymerizations in water. J. Macromol. Sci. A 2001, 38, 1219-1230.

118. Singh, A.; Kaplan, D.L. Vitamin C functionalized poly(methyl methacrylate) for free radical scavenging. J. Macromol. Sci. Part A 2004, 41, 1377-1386.

119. Singh, A.; Kaplan, D.L. Biocatalytic route to ascorbic acid-modified polymers for free-radical scavenging. Adv. Mat. 2003, 15, 1291-1294.

120. Bruno, F.F.; Trotta, A.; Fossey, S.; Nagarajan, S.; Nagarajan, R.; Samuelson, L.A.; Kumar, J. Enzymatic synthesis and characterization of poly quercetin. J. Macromol. Sci. Part A 2010, 47, 1191-1196.

121. Desentis-Mendoza, R.M.; Hernandez-Sanchez, H.; Moreno, A.; Emilio, R.D.C.; Chel-Guerrero, L.; Tamariz, J.; Jaramillo-Flores, M.E. Enzymatic polymerization of phenolic compounds using laccase and tyrosinase from Ustilago maydis. Biomacromolecules 2006, 7, 1845-1854.

122. Ma, H.-L.; Kermasha, S.; Gao, J.-M.; Borges, R.M.; Yu, X.-Z. Laccase-catalyzed oxidation of phenolic compounds in organic media. J. Mol. Catal. B 2009, 57, 89-95.

123. Kurisawa, M.; Chung, J.E.; Uyama, H.; Kobayashi, S. Laccase-catalyzed synthesis and antioxidant property of poly(catechin). Macromol. Biosci. 2003, 3, 758-764.

124. Bruno, F.F.; Nagarajan, S.; Nagarajan, R.; Kumar, J.; Samuelson, L.A. Biocatalytic synthesis of water-soluble oligo(catechins). J. Macromol. Sci. 2005, A42, 1547-1554.

125. Anthoni, J.; Chebil, L.; Lionneton, F.; Magdalou, J.; Humeau, C.; Ghoul, M. Automated analysis of synthesized oligorutin and oligoesculin by laccase. Can. J. Chem. 2011, 89, 964-970.

126. Anthoni, J.; Humeau, C.; Maia, E.R.; Chebil, L.; Engasser, J.M.; Ghoul, M. Enzymatic synthesis of oligoesculin: Structure and biological activities characterizations. Eur. Food Res. Technol. 2010, 231, 571-579.

127. Kurisawa, M.; Chung, J.E.; Uyama, H.; Kobayashi, S. Enzymatic synthesis and antioxidant properties of poly(rutin). Biomacromolecules 2003, 4, 1394-1399.

128. Uzan, E.; Portet, B.; Lubrano, C.; Milesi, S.; Favel, A.; Lesage-Meessen, L.; Lomascolo, A. Pycnoporus laccase-mediated bioconversion of rutin to oligomers suitable for biotechnology applications. Appl. Microbiol. Biotechnol. 2011, 90, 97-105.

129. Kurisawa, M.; Chung, J.E.; Uyama, H.; Kobayashi, S. Oxidative coupling of epigallocatechin gallate amplifies antioxidant activity and inhibits xanthine oxidase activity. Chem. Commun. 2004, 294-295. 
130. Kudanga, T.; Nyanhongo, G.S.; Guebitz, G.M.; Burton, S. Potential applications of laccase-mediated coupling and grafting reactions: A review. Enzym. Microb. Technol. 2011, 48, 195-208.

131. Chung, J.E.; Kurisawa, M.; Tachibana, Y.; Uyama, H.; Kobayashi, S. Enzymatic synthesis and antioxidant property of poly(allylamine)-catechin conjugate. Chem. Lett. 2003, 32, 620-621.

132. Gogoi, P.; Hazarika, S.; Dutta, N.N.; Rao, P.G. Kinetics and mechanism on laccase catalyzed synthesis of poly(allylamine)-catechin conjugate. Chem. Eng. J. 2010, 163, 86-92.

133. Gogoi, P.; Hazarika, S.; Dutta, N.N.; Rao, P.G. Laccase catalysed conjugation of catechin with poly(allylamine): Solvent effect. Chem. Eng. J. 2009, 155, 810-815.

134. Chung, J.E.; Kurisawa, M.; Uyama, H.; Kobayashi, S. Enzymatic synthesis and antioxidant property of gelatin-catechin conjugates. Biotechnol. Lett. 2003, 25, 1993-1997.

135. Gaffar Hossain, K.M.; Díaz González, M.; Monmany, J.M.D.; Tzanov, T. Effects of alkyl chain lengths of gallates upon enzymatic wool functionalisation. J. Mol. Catal. B 2010, 67, 231-235.

136. Vachoud, L.; Chen, T.; Payne, G.F.; Vazquez-Duhalt, R. Peroxidase catalyzed grafting of gallate esters onto the polysaccharide chitosan. Enzym. Microb. Technol. 2001, 29, 380-385.

137. Cho, Y.S.; Kim, S.K.; Ahn, C.B.; Je, J.Y. Preparation, characterization, and antioxidant properties of gallic acid-grafted-chitosans. Carbohydr. Polym. 2011, 83, 1617-1622.

138. Vartiainen, J.; Rättö, M.; Lantto, R.; Nättinen, K.; Hurme, E. Tyrosinase-catalysed grafting of food-grade gallates to chitosan: Surface properties of novel functional coatings. Packag. Technol. Sci. 2008, 21, 317-328.

139. Pasanphan, W.; Buettner, G.R.; Chirachanchai, S. Chitosan gallate as a novel potential polysaccharide antioxidant: An EPR study. Carbohydr. Res. 2010, 345, 132-140.

140. Aljawish, A.; Chevalot, I.; Piffaut, B.; Rondeau-Mouro, C.; Girardin, M.; Jasniewski, J.; Scher, J.1.; Muniglia, L. Functionalization of chitosan by laccase-catalyzed oxidation of ferulic acid and ethyl ferulate under heterogeneous reaction conditions. Carbohydr. Polym. 2012, 87, 537-544.

141. Sousa, F.; Guebitz, G.M.; Kokol, V. Antimicrobial and antioxidant properties of chitosan enzymatically functionalized with flavonoids. Proc. Biochem. 2009, 44, 749-756.

142. Ihara, N.; Kurisawa, M.; Chung, J.E.; Uyama, H.; Kobayashi, S. Enzymatic synthesis of a catechin conjugate of polyhedral oligomeric silsesquioxane and evaluation of its antioxidant activity. Appl. Microbiol. Biotechnol. 2005, 66, 430-433.

143. Kim, S.; Cavaco-Paulo, A. Laccase-catalysed protein-flavonoid conjugates for flax fibre modification. Appl. Microbiol. Biotechnol. 2012, 93, 585-600.

144. Silva, C.; Matama, T.; Kim, S.; Padrao, J.; Nugroho Prasetyo, E.; Kudanga, T.; Nyanhongo, G.S.; Guebitz, G.M.; Casal, M.; Cavaco-Paulo, A. Antimicrobial and antioxidant linen via laccase-assisted grafting. React. Funct. Polym. 2011, 71, 713-720.

145. Chen, T.; Kumar, G.; Harris, M.T.; Smith, P.J.; Payne, G.F. Enzymatic grafting of hexyloxyphenol onto chitosan to alter surface and rheological properties. Biotechnol. Bioeng. 2000, 70, 564-573.

146. Brzonova, I.; Steiner, W.; Zankel, A.; Nyanhongo, G.S.; Guebitz, G.M. Enzymatic synthesis of catechol and hydroxyl-carboxic acid functionalized chitosan microspheres for iron overload therapy. Eur. J. Pharm. Biopharm. 2011, 79, 294-303.

147. Matheis, G.; Whitaker, J.R. Peroxidase-catalyzed cross linking of proteins. J. Protein Chem. 1984, 3, 35-48. 
148. Oudgenoeg, G.; Hilhorst, R.; Piersma, S.R.; Boeriu, C.G.; Gruppen, H.; Hessing, M.; Voragen, A.G.J.; Laane, C. Peroxidase-mediated cross-linking of a tyrosine-containing peptide with ferulic acid. J. Agric. Food Chem. 2001, 49, 2503-2510.

149. Mattinen, M.L.; Hellman, M.; Permi, P.; Autio, K.; Kalkkinen, N.; Buchert, J. Effect of protein structure on laccase-catalyzed protein oligomerization. J. Agric. Food Chem. 2006, 54, 8883-8890.

150. Minamihata, K.; Goto, M.; Kamiya, N. Site-specific protein cross-linking by peroxidase-catalyzed activation of a tyrosine-containing peptide tag. Bioconjugate Chem. 2011, 22, 74-81.

151. Kuuva, T.; Lantto, R.; Reinikainen, T.; Buchert, J.; Autio, K. Rheological properties of laccase-induced sugar beet pectin gels. Food Hydrocoll. 2003, 17, 679-684.

152. Micard, V.; Thibault, J.F. Oxidative gelation of sugar-beet pectins: Use of laccases and hydration properties of the cross-linked pectins. Carbohydr. Polym. 1999, 39, 265-273.

153. Chen, B.; McClements, D.J.; Gray, D.A.; Decker, E.A. Stabilization of soybean oil bodies by enzyme (laccase) cross-linking of adsorbed beet pectin coatings. J. Agric. Food Chem. 2010, 58, 9259-9265.

154. Ogushi, Y.; Sakai, S.; Kawakami, K. Synthesis of enzymatically-gellable carboxymethylcellulose for biomedical applications. J. Biosci. Bioeng. 2007, 104, 30-33.

155. Sakai, S.; Hashimoto, I.; Ogushi, Y.; Kawakami, K. Peroxidase-catalyzed cell encapsulation in subsieve-size capsules of alginate with phenol moieties in water-immiscible fluid dissolving $\mathrm{H}_{2} \mathrm{O}_{2}$. Biomacromolecules 2007, 8, 2622-2626.

156. Lee, F.; Chung, J.E.; Kurisawa, M. An injectable enzymatically crosslinked hyaluronic acid-tyramine hydrogel system with independent tuning of mechanical strength and gelation rate. Soft Matter 2008, 4, 880-887.

157. Jin, R.; Hiemstra, C.; Zhong, Z.Y.; Feijen, J. Enzyme-mediated fast in situ formation of hydrogels from dextran-tyramine conjugates. Biomaterials 2007, 28, 2791-2800.

158. Park, K.M.; Shin, Y.M.; Joung, Y.K.; Shin, H.; Park, K.D. In situ forming hydrogels based on tyramine conjugated 4-Arm-PPO-PEO via enzymatic oxidative reaction. Biomacromolecules 2010, 11, 706-712.

159. Sakai, S.; Yamada, Y.; Zenke, T.; Kawakami, K. Novel chitosan derivative soluble at neutral pH and in situ gellable via peroxidase-catalyzed enzymatic reaction. J. Mater. Chem. 2009, 19, 230-235.

160. Jayakumar, R.; Prabaharan, M.; Reis, R.L.; Mano, J.F. Graft copolymerized chitosan-Present status and applications. Carbohydr. Polym. 2005, 62, 142-158.

161. Kumar, G.; Smith, P.J.; Payne, G.F. Enzymatic grafting of a natural product onto chitosan to confer water solubility under basic conditions. Biotechnol. Bioeng. 1999, 63, 154-165.

162. Mai, C.; Milstein, O.; Hüttermann, A. Fungal laccase grafts acrylamide onto lignin in presence of peroxides. Appl. Microbiol. Biotechnol. 1999, 51, 527-531.

163. Mai, C.; Milstein, O.; Hüttermann, A. Chemoenzymatical grafting of acrylamide onto lignin. J. Biotechnol. 2000, 79, 173-183.

164. Tsujimoto, T.; Ando, N.; Oyabu, H.; Uyama, H.; Kobayashi, S. Laccase-catalyzed curing of natural phenolic lipids and product properties. J. Macromol. Sci. A 2007, 44, 1055-1060.

165. Tsujimoto, T.; Ikeda, R.; Uyama, H.; Kobayashi, S. Crosslinkable polyphenols from urushiol analogues. Macromol. Chem. Phys. 2001, 202, 3420-3425. 
166. Kobayashi, S.; Uyama, H.; Ikeda, R. Artificial urushi. Chem. Eur. J. 2001, 7, 4755-4760.

167. Ikeda, R.; Tanaka, H.; Oyabu, H.; Uyama, H.; Kobayashi, S. Preparation of artificial urushi via an environmentally benign process. Bull. Chem. Soc. Japan 2001, 74, 1067-1073.

168. Park, S.Y.; Kim, Y.H.; Won, K.; Song, B.K. Enzymatic synthesis and curing of polycardol from renewable resources. J. Mol. Catal. B. 2009, 57, 312-316.

169. Kim, Y.H.; Won, K.; Kwon, J.M.; Jeong, H.S.; Park, S.Y.; An, E.S.; Song, B.K. Synthesis of polycardanol from a renewable resource using a fungal peroxidase from Coprinus cinereus. J. Mol. Catal. B 2005, 34, 33-38.

170. Kim, Y.H.; An, E.S.; Song, B.K.; Kim, D.S.; Chelikani, R. Polymerization of cardanol using soybean peroxidase and its potential application as anti-biofilm coating material. Biotechnol. Lett. 2003, 25, 1521-1524.

171. Reihmann, M.H.; Ritter, H. Enzymatically catalyzed synthesis of photocrosslinkable oligophenols. Macromol. Chem. Phys. 2000, 201, 1593-1597.

172. Bilici, A.; Kaya, I.; Yildirim, M. Peroxidase-catalyzed synthesis of polyphenols bearing aldehyde units. Des. Monomers Polym. 2011, 14, 353-366.

173. Majeau, J.A.; Brar, S.K.; Tyagi, R.D. Laccases for removal of recalcitrant and emerging pollutants. Biores. Technol. 2010, 101, 2331-2350.

174. Husain, Q. Peroxidase mediated decolorization and remediation of wastewater containing industrial dyes: A review. Rev. Environ. Sci. Bio Technol. 2010, 9, 117-140.

175. Minussi, R.C.; Pastore, G.M.; Duran, N. Potential applications of laccase in the food industry. Trends Food Sci. Technol. 2002, 13, 205-216.

176. Lopez, C.; Moreira, M.T.; Feijoo, G.; Lema, J.M. Economic comparison of enzymatic reactors and advanced oxidation processes applied to the degradation of phenol as a model compound. Biocatal. Biotransf. 2011, 29, 344-353.

177. Kadhim, H.; Graham, C.; Barratt, P.; Evans, C.S.; Rastall, R.A. Removal of phenolic compounds in water using Coriolus versicolor grown on wheat bran. Enz. Microb. Technol. 1999, 24, 303-307.

178. Uhnakova, B.; Ludwig, R.; Peknicova, J.; Homolka, L.; Lisa, L.; Sulc, M.; Petrickova, A.; Elzeinova, F.; Pelantova, H.; Monti, D.; et al. Biodegradation of tetrabromobisphenol A by oxidases in basidiomycetous fungi and estrogenic activity of the biotransformation products. Bioresour. Technol. 2011, 102, 9409-9415.

179. Gaitan, I.J.; Medina, S.C.; Gonzalez, J.C.; Rodriguez, A.; Espejo, A.J.; Osma, J.F.; Sarria, V.; Almeciga-Diaz, C.J.; Sanchez, O.F. Evaluation of toxicity and degradation of a chlorophenol mixture by the laccase produced by Trametes pubescens. Bioresour. Technol. 2011, 102, 3632-3635.

180. Lisov, A.V.; Pozhidaeva, Z.A.; Stepanova, E.V.; Koroleva, O.V.; Leontievsky, A.A. Conversion of polychloronhenols by laccases with 1-hydroxybenzotriazole as a mediator. Appl. Biochem. Microbiol. 2007, 43, 616-619.

181. Leontievsky, A.A.; Myasoedova, N.M.; Baskunov, B.P.; Evans, C.S.; Golovleva, L.A. Transformation of 2,4,6-trichlorophenol by the white rot fungi Panus tigrinus and Coriolus versicolor. Biodegradation 2000, 11, 331-340. 
182. Schultz, A.; Jonas, U.; Hammer, E.; Schauer, F. Dehalogenation of chlorinated hydroxybiphenyls by fungal laccase. Appl. Environ. Microbiol. 2001, 67, 4377-4381.

183. Watanabe, C.; Kashiwada, A.; Matsuda, K.; Yamada, K. Soybean peroxidase-catalyzed treatment and removal of BPA and bisphenol derivatives from aqueous solutions. Environ. Prog. Sustain. Energy 2011, 30, 81-91.

184. Fukuda, T.; Uchida, H.; Suzuki, M.; Miyamoto, H.; Morinaga, H.; Nawata, H.; Uwajima, T. Transformation products of bisphenol A by a recombinant Trametes vilosa laccase and their estrogenic activity. J. Chem. Technol. Biotechnol. 2004, 79, 1212-1218.

185. Tsutsumi, Y.; Haneda, T.; Nishida, T. Removal of estrogenic activities of bisphenol A and nonylphenol by oxidative enzymes from lignin-degrading basidiomycetes. Chemosphere 2001, $42,271-276$.

186. Lloret, L.; Hollmann, F.; Eibes, G.; Feijoo, G.; Moreira, M.; Lema, J. Immobilisation of laccase on Eupergit supports and its application for the removal of endocrine disrupting chemicals in a packed-bed reactor. Biodegradation 2012, 1-14.

187. Lloret, L.; Eibes, G.; Feijoo, G.; Moreira, M.T.; Lema, J.M.; Hollmann, F. Immobilization of laccase by encapsulation in a sol-gel matrix and its characterization and use for the removal of estrogens. Biotechnol. Prog. 2011, 27, 1570-1579.

188. Lloret, L.; Eibes, G.; Lu-Chau, T.A.; Moreira, M.T.; Feijoo, G.; Lema, J.M. Laccase-catalyzed degradation of anti-inflammatories and estrogens. Biochem. Eng. J. 2010, 51, 124-131.

189. Wang, C.J.; Thiele, S.; Bollag, J.M. Interaction of 2,4,6-trinitrotoluene (TNT) and 4-amino-2,6-dinitrotoluene with humic monomers in the presence of oxidative enzymes. Arch. Environ. Contam. Toxicol. 2002, 42, 1-8.

190. Thiele, S.; Fernandes, E.; Bollag, J.M. Enzymatic transformation and binding of labeled 2,4,6-trinitrotoluene to humic substances during an anaerobic/aerobic incubation. J. Environ. Qual. 2002, 31, 437-444.

191. Collins, P.J.; Kotterman, M.J.J.; Field, J.A.; Dobson, A.D.W. Oxidation of anthracene and benzo[a]pyrene by laccases from Trametes versicolor. Appl. Environ. Microbiol. 1996, 62, 4563-4567.

192. Zeng, J.; Lin, X.G.; Zhang, J.; Li, X.Z.; Wong, M.H. Oxidation of polycyclic aromatic hydrocarbons by the bacterial laccase CueO from E. coli. Appl. Microbiol. Biotechnol. 2011, 89, 1841-1849.

193. Wang, J.Q.; Ogata, M.; Hirai, H.; Kawagishi, H. Detoxification of aflatoxin B(1) by manganese peroxidase from the white-rot fungus Phanerochaete sordida YK-624. FEMS Microbiol. Lett. 2011, 314, 164-169.

194. Eibes, G.; Cajthaml, T.; Moreira, M.T.; Feijoo, G.; Lema, J.M. Enzymatic degradation of anthracene, dibenzothiophene and pyrene by manganese peroxidase in media containing acetone. Chemosphere 2006, 64, 408-414.

195. Eibes, G.; Lu-Chau, T.; Feijoo, G.; Moreira, M.T.; Lema, J.M. Complete degradation of anthracene by Manganese Peroxidase in organic solvent mixtures. Enzym. Microb. Technol. 2005, 37, 365-372.

196. Mielgo, I.; Lopez, C.; Moreira, M.T.; Feijoo, G.; Lema, J.M. Oxidative degradation of azo dyes by manganese peroxidase under optimized conditions. Biotechnol. Prog. 2003, 19, 325-331. 
197. Minussi, R.C.; Miranda, M.A.; Silva, J.A.; Ferreira, C.V.; Aoyama, H.; Marangoni, S.; Rotilio, D.; Pastore, G.M.; Duran, N. Purification, characterization and application of laccase from Trametes versicolor for colour and phenolic removal of olive mill wastewater in the presence of 1-hydroxybenzotriazole. Afr. J. Biotechnol. 2007, 6, 1248-1254.

198. Suda, T.; Hata, T.; Kawai, S.; Okamura, H.; Nishida, T. Treatment of tetracycline antibiotics by laccase in the presence of 1-hydroxybenzotriazole. Bioresour. Technol. 2012, 103, 498-501.

199. Gross, R.A.; Kumar, A.; Kalra, B. Polymer synthesis by in vitro enzyme catalysis. Chem. Rev. 2001, 101, 2097-2124.

(C) 2012 by the authors; licensee MDPI, Basel, Switzerland. This article is an open access article distributed under the terms and conditions of the Creative Commons Attribution license (http://creativecommons.org/licenses/by/3.0/). 